NBER WORKING PAPER SERIES

\title{
UNCERTAIN FISCAL CONSOLIDATIONS
}

\author{
Huixin $\mathrm{Bi}$ \\ Eric M. Leeper \\ Campbell B. Leith \\ Working Paper 17844 \\ http://www.nber.org/papers/w17844
NATIONAL BUREAU OF ECONOMIC RESEARCH
1050 Massachusetts Avenue
Cambridge, MA 02138
February 2012

We are grateful to Alberto Alesina and Silvia Ardagna for providing us with their dataset. We thank Nicoletta Batini, Paul Beaudry, Isabel Correia, Tobias Cwik, Michael Devereux, Kenneth Kletzer, Charles Nolan, Federico Ravenna, Gregor Smith, Harald Uhlig, Juergen von Hagen and participants at the Swiss National Bank workshop, the Bank of Canada Fellowship workshop, the European Economic Review Young Economist Workshop, and the Conference on Monetary Policy in an Era of Fiscal Stress at Riksbank for many useful comments. Campbell Leith is grateful for financial support from the ESRC, Grant No. RES-062-23-1436. The views expressed in this paper are those of the authors and not of the Bank of Canada or the National Bureau of Economic Research.

NBER working papers are circulated for discussion and comment purposes. They have not been peerreviewed or been subject to the review by the NBER Board of Directors that accompanies official NBER publications.

(C) 2012 by Huixin Bi, Eric M. Leeper, and Campbell B. Leith. All rights reserved. Short sections of text, not to exceed two paragraphs, may be quoted without explicit permission provided that full credit, including $($ ) notice, is given to the source. 
Uncertain Fiscal Consolidations

Huixin Bi, Eric M. Leeper, and Campbell B. Leith

NBER Working Paper No. 17844

February 2012

JEL No. E3,E31,E52,E62

\section{ABSTRACT}

The paper explores the macroeconomic consequences of fiscal consolidations whose timing and composition are uncertain. Drawing on the evidence in Alesina and Ardagna (2010), we emphasize whether or not the fiscal consolidation is driven by tax rises or expenditure cuts. We find that the composition of the fiscal consolidation, its duration, the monetary policy stance, the level of government debt and expectations over the likelihood and composition of fiscal consolidations all matter in determining the extent to which a given consolidation is expansionary and/or successful in stabilizing government debt.

Huixin Bi

Bank of Canada

234 Wellington Street

Ottawa

Ontario K1A0G9

Canada

bihu@bankofcanada.ca

Eric M. Leeper

Department of Economics

304 Wylie Hall

Indiana University

Bloomington, IN 47405

and Monash University, Australia

and also NBER

eleeper@indiana.edu
Campbell B. Leith

Department of Economics

University of Glasgow

Glasgow, G12 8QQ, Scotland

campbell.leith@glasgow.ac.uk 


\title{
Uncertain Fiscal Consolidations*
}

\author{
Huixin Bi† Eric M. Leeper; and Campbell Leith ${ }^{\S}$
}

\section{INTRODUCTION}

The financial crisis of 2007-09 has left the advanced economies with average levels of gross government debt breaching 100 percent level of GDP for the first time since the aftermath of World War II, see International Monetary Fund (2011). As a result, the IMF expects most governments of such economies, except for Japan and the United States, to begin consolidation efforts by 2012. Politicians in some countries, such as the United Kingdom, argue that fiscal consolidations will ultimately enhance growth, and they cite the need to avoid rising debt costs as a key motivation in undertaking fiscal consolidations. Evidently, the dominant medium-term fiscal trend in advanced economies is a return to a position of fiscal sustainability, particularly when prompted to do so under financial market pressure.

Conventional Keynesian analysis suggests that fiscal consolidations inevitably contract aggregate demand and reduce output. Giavazzi and Pagano's (1990) analysis of fiscal consolidations in Denmark and Ireland in the 1980s, however, suggests that such fiscal actions could be expansionary, because output growth actually accelerated after these fiscal tightenings. Subsequent empirical work considers a wider set of countries over a wider time period and also finds some evidence that fiscal consolidations can be expansionary. ${ }^{1}$ It appears that the persistence and composition of the consolidation often matters, with government

\footnotetext{
*February 8, 2012. We are grateful to Alberto Alesina and Silvia Ardagna for providing us with their dataset. We thank Nicoletta Batini, Paul Beaudry, Isabel Correia, Tobias Cwik, Michael Devereux, Kenneth Kletzer, Charles Nolan, Federico Ravenna, Gregor Smith, Harald Uhlig, Jürgen von Hagen and participants at the Swiss National Bank workshop, the Bank of Canada Fellowship workshop, the European Economic Review Young Economist Workshop, and the Conference on Monetary Policy in an Era of Fiscal Stress at Riksbank for many useful comments. Campbell Leith is grateful for financial support from the ESRC, Grant No. RES-062-23-1436. The views expressed in this paper are those of the authors and not of the Bank of Canada.

${ }^{\dagger}$ Bank of Canada, 234 Wellington Street, Ottawa, ON K1A 0G9, Canada; hbi@bankofcanada.ca

${ }^{\ddagger}$ Indiana University, Monash University, and NBER, 105 Wylie Hall, Bloomington, IN 47405, United States; eleeper@indiana.edu

§University of Glasgow, Adam Smith Building, Glasbow G12 8RT, United Kingdom; Campbell.Leith@glasgow.ac.uk

${ }^{1}$ Briotti (2005) surveys the literature.
} 
spending cuts being thought to be pro-growth relative to tax increases (see, for example, Alesina and Perotti (1995), Perotti (1996), Alesina and Ardagna (1998, 2010), and Ardagna (2004)).

Theoretical mechanisms underpinning the empirical results have been discussed. In particular, Bertola and Drazen (1993) develop a model where government spending is inherently unsustainable, but the government will satisfy its intertemporal budget constraint by periodically cutting spending. These consolidations may occur at a low threshold, but if not, they will definitely occur at a second, higher threshold. A worsening fiscal position raises the probability of soon entering a period of beneficial fiscal correction and, therefore, can lead to an expansion. ${ }^{2}$ While Bertola and Drazen (1993) is often cited as an example of the importance of expectations when considering the impact of fiscal consolidations, it cannot address questions relating to the composition of consolidations, which the empirical literature often finds important. Our analysis begins by adding distorting taxes to Bertola and Drazen's (1993) model to highlight how uncertainty over the timing and the composition of fiscal compositions can affect whether or not a realized consolidation is expansionary.

Following this simple example, we develop a non-linear DSGE model, in which fiscal consolidations may occur with an increasing probability as government debt levels rise, but the exact timing is uncertain. It is consistent with the empirical observation that sizeable consolidations can take place at low- as well as high-debt levels. We also introduce uncertainty over the composition of fiscal consolidation, either tax- or spending-based, building on the dataset by Alesina and Ardagna (2010). We find that the nature of fiscal consolidation, its duration, the expectations over its likelihood and composition, the monetary policy stance, and the level of government debt all matter in determining the extent to which a given consolidation is expansionary and/or successful in stabilizing government debt. When debt levels are high, the inflationary consequences of alternative fiscal instruments, conditional on the stance of monetary policy, are particularly important in determining the impact of alternative forms of fiscal consolidation. For example, when economic agents anticipate tax increases under an imminent fiscal consolidation package, they will suffer the ill-effects of distortionary taxation, including higher inflation and, when monetary policy is active, higher debt service costs, even if the realized consolidation is ultimately spending based. As a result, the resolution of the uncertainty associated with the composition or the timing can have a significant impact on the nature of the marginal economic response to the consolidation.

Such non-linear interactions among debt levels, the monetary policy stance, the composi-

\footnotetext{
${ }^{2}$ Similarly, Sutherland (1997) suggests that there will be non-linearities in the economic impact of fiscal policy when debt levels affect the timing of fiscal consolidations in an overlapping generations economy. Alesina and Perotti (1997) also argue that the response to changes in tax rates may be quite different depending on the extent and nature of union wage bargaining.
} 
tions of consolidations, and the expectations about the nature of consolidations are unlikely to be controlled for by adding individual variables to linear regressions or by sorting samples conditional on a single variable. This may explain why the empirical literature does not always fully agree on the relative importance of different factors in determining whether or not a consolidation is expansionary and/or successful. In many cases, one study finds a conditioning variable to be significant, while another study does not. ${ }^{3}$

The next section discusses empirical evidence in Alesina and Ardagna (2010), who analyze the large-scale fiscal consolidations within OECD countries between 1970 and 2007. Section 3 lays out a simple economy where uncertainty over the timing and the composition of fiscal consolidations can be expansionary in a neoclassical setting. Section 4 outlines the richer new Keynesian model and the range of state-dependent fiscal consolidations that may occur. Section 5 describes the fiscal limit that determines the state-dependent probability of observing a fiscal consolidation and section 6 describes the calibration and solution for the non-linear model. Sections 7 and 8 present the model's implications for a wide range of fiscal consolidations. Section 9 concludes.

\section{Fiscal Consolidations Data}

Alesina and Ardagna (2010) (henceforth AA) analyze episodes of fiscal stimulus (rise in deficit/fall in surplus) and consolidation (fall in deficit/rise in surplus) of more than 1.5 percent of GDP, where the data are cyclically adjusted. They classify a episode as "expansionary" if GDP growth in the two years following the stimulus/consolidation is greater than the 75 th percentile of the empirical density in all episodes. They also define a "successful" fiscal consolidation as one that reduces the debt-GDP ratio by 4.5 percent three years later. Based on a sample of developed economies between 1970 and 2007, 107 episodes are fiscal consolidations, which is 15.1 percent of the observations.

We follow AA to compute the average change in key fiscal variables in the two years following a fiscal consolidation relative to the two years prior to the adjustment. Our numbers differ slightly from those in AA as we exclude consolidations where we do not have observations either before or after the episode. ${ }^{4}$ Table 1 details the average change in fiscal variables under both types of consolidation, where all variables are measured relative to output. It reveals some striking differences between "expansionary" and "contractionary" consolidations

\footnotetext{
${ }^{3}$ For example, Lambertini and Tavares (2005) find that accompanying exchange rate devaluations help ensure fiscal consolidations are successful, but Ardagna (2004) does not; and while Alesina and Ardagna (2010) find that the composition of consolidations affects both how expansionary and successful a consolidation is, Ardagna (2004) argues that composition does not matter for success.

${ }^{4}$ We do this because we wish to assess the statistical significance of the changes in fiscal variables over the course of a consolidation episode.
} 
that meet AA's definitions. "Expansionary" consolidations feature a statistically significant fall in government spending of 2.19 percent of GDP, and a statistically insignificant rise in tax revenues of 0.35 percent and fall in transfers of 0.58 percent of GDP. In contrast, contractionary consolidations entail a fall in government spending of only 0.8 percent, and rises in tax revenues of 1.11 percent and in transfers of 0.47 percent, all of which are statistically significant.

The "expansionary" fiscal consolidations appear to be driven by spending cuts with no significant increases in aggregate tax revenues, while the "contractionary" episodes are far more heavily dependent on increases in taxation. AA also observe that one out of four fiscal consolidations are "expansionary", and that out of 107 fiscal consolidations, 65 last for one year, 13 last two years, 4 last three years and 1 lasts for four years. We use these observations to calibrate both the consolidation duration and the relative frequency of spending- and taxbased consolidations in the following sections.

\section{Simple Model of Fiscal Consolidation}

In this section we use a small, open economy to highlight the role expectations may play in determining whether or not a fiscal consolidation is expansionary. We augment Bertola and Drazen's (1993) model with distortionary taxation. The small, open economy assumption allows us to generate analytical results in an endowment economy in which households still face meaningful consumption/saving decisions. Uncertainty over both the composition and the timing of fiscal consolidations generate expectation effects that have implications for the existence of expansionary consolidations.

A representative household maximizes utility according to,

$$
\begin{aligned}
& E_{t} \sum_{s=0}^{\infty} \beta^{s} c_{t+s}^{2} \\
& \text { s.t. } \quad \beta a_{t+1}=a_{t}+y\left(1-\tau_{t}-\psi\left(\tau_{t}\right)^{2}\right)-c_{t}
\end{aligned}
$$

where $y$ is the household's endowment income. The holdings of financial assets at the start of period $\left(a_{t}\right)$ earn a world interest rate of $1 / \beta . \tau_{t}$ is the tax rate on endowment income, which carries deadweight losses of $y \psi\left(\tau_{t}\right)^{2}$. Deadweight losses can be motivated by tax avoidance activities in an environment where the fiscal authorities find it difficult to measure the household's income, but more generally they capture the costs of distortionary taxation in economies with a more sophisticated supply side. ${ }^{5}$ The household's intertemporal budget

\footnotetext{
${ }^{5}$ In the New Keynesian DSGE model we consider below, other than the standard mechanism of taxes distorting labor supply decisions, sticky prices imply additional distortions caused by the inflation consequences
} 
constraint is,

$$
\sum_{s=0}^{\infty} \beta^{s} E_{t} c_{t+s}=a_{t}+E_{t} \sum_{s=0}^{\infty} \beta^{s} y\left(1-\tau_{t+s}-\psi\left(\tau_{t+s}\right)^{2}\right)
$$

With quadratic utility, the household's first-order condition delivers pure consumption smoothing,

$$
c_{t}=E_{t} c_{t+s}
$$

Only surprises in the either the composition or the timing of fiscal consolidations give rise to jumps in consumption, while anticipated cuts in government spending and/or tax rises affect consumption only at the time when they are news.

The government's flow budget constraint is,

$$
\beta b_{t+1}=b_{t}-y \tau_{t}+g_{t}
$$

implying the intertemporal constraint

$$
b_{t}=E_{t} \sum_{s=0}^{\infty} \beta^{s} y \tau_{t+s}-E_{t} \sum_{s=0}^{\infty} \beta^{s} g_{t+s}
$$

Imposing equilibrium - equations (4) and (6) - the household's intertemporal budget constraint implies,

$$
\frac{c_{t}}{1-\beta}=\left(a_{t}-b_{t}\right)+E_{t} \sum_{s=0}^{\infty} \beta^{s} y\left(1-\psi\left(\tau_{t+s}\right)^{2}\right)-E_{t} \sum_{s=0}^{\infty} \beta^{s} g_{t+s}
$$

where $a_{t}-b_{t}$ are the net foreign assets held by households. At time $t$, the right side of equation (7) is predetermined or exogenous to the household, so we can use this expression to consider the impact on consumption of alternative compositions and timings of fiscal consolidations.

Assume the initial levels of government spending, $g^{0}$, and tax rates, $\tau^{0}$, are insufficient to satisfy the government's intertemporal constraint, (6), then debt is increasing and government spending or taxes must change in the future for the debt to have value in equilibrium. After $n$ periods, debt reaches a level $b_{t+n}$, found by accumulating the government's flow budget constraint forwards $n$ periods.

$$
b_{t+n}=\beta^{-n} b_{t}-\beta^{-n} \sum_{s=0}^{n-1} \beta^{s} y \tau^{0}+\beta^{-n} \sum_{s=0}^{n-1} \beta^{s} g^{0}
$$

of changes in distortionary taxation. 
We now consider two types of uncertainty: uncertainty in the timing of the fiscal consolidation and uncertainty in the composition.

3.1 The Timing of Consolidations In this model, there is only one channel through which the timing of fiscal consolidations can affect the likelihood of an expansionary consolidation: the non-linearities associated with the deadweight losses caused by distortionary taxation. To satisfy the government's budget constraint, some combination of spending cuts or tax increases must be implemented to stabilize debt. In the absence of deadweight losses, the timing of these tax and expenditure changes cannot matter-unexpected delays in fiscal consolidation would have no effect, so long as fiscal policy ultimately satisfies the intertemporal budget constraint. In the presence of deadweight losses, however, the discounted value of these losses erode the resources available to the household for consumption. To the extent that a tax-based consolidation is delayed, the required tax increase rises, and the deadweight losses associated with the consolidation rise even faster.

Consider the household's consumption decision, equation (7), when only taxes adjust to stabilize debt. Using $b_{t}-g^{0} /(1-\beta)=E_{t} \sum_{s} \beta^{s} y \tau_{t+s}$ from equation (6), the consumption decision becomes,

$$
\frac{c_{t}}{1-\beta}=a_{t}+E_{t} \sum_{s=0}^{\infty} \beta^{s} y\left(1-\tau_{t+s}-\psi\left(\tau_{t+s}\right)^{2}\right)
$$

Altering the timing of a tax-based consolidation does not affect the size of the discounted tax revenues needed to maintain fiscal solvency, but does affect the expected discounted sum of the deadweight losses,

$$
E_{t} \sum_{s=0}^{\infty} \beta^{s} y\left(\psi\left(\tau_{t+s}\right)^{2}\right)
$$

From familiar tax smoothing arguments, the discounted sum of these deadweight losses is minimized by an immediate one-off increase in the tax rate to a level sufficient to satisfy the government's budget. Any delay in the implementation of the consolidation deviates from tax smoothing and raises the discounted value of deadweight losses. Accordingly, unexpected delay in a tax-based consolidation reduces consumption, while an unexpectedly prompt consolidation increases it.

3.2 Composition UnCertainty To model composition uncertainty, assume that households expect a fiscal consolidation $n$ periods from now, with fiscal policy changing taxes or government spending to new levels that satisfy (6) at period $t+n$. Households expect the consolidation to be spending-based with probability $q$, and tax-based with probability $1-q$. To stabilize debt at $b_{t+n}$, a spending-based consolidation sets $g^{1}$ from period $t+n$ onwards 
to satisfy,

$$
g^{1}=y \tau^{0}-(1-\beta) b_{t+n}
$$

where tax rates remain at $\tau^{0}$. In the case of a tax-based consolidation, the new tax rate, $\tau^{1}$ solves,

$$
y \tau^{1}=g^{0}+(1-\beta) b_{t+n}
$$

Government-spending based consolidation requires a cut in spending and a tax-based consolidation requires an increase in tax revenues of an equal amount to ensure that debt is stabilized at the level $b_{t+n}$ from that point onwards. Consumption under each type of consolidation, from period $t+n$ onwards is,

$$
\begin{aligned}
c^{t a x} & =(1-\beta)\left(a_{t+n}-b_{t+n}\right)+y\left(1-\psi\left(\tau^{1}\right)^{2}\right)-g^{0} \\
c^{\text {spending }} & =(1-\beta)\left(a_{t+n}-b_{t+n}\right)+y\left(1-\psi\left(\tau^{0}\right)^{2}\right)-g^{1}
\end{aligned}
$$

Before consolidation, consumption lies between these two cases, so that there will be a positive (negative) jump in consumption at the point when the consolidation is revealed to be spending- (tax-) based. The exact size of the jump depends on expectations prior to the realization of the consolidation. Consumption prior to the consolidation is,

$$
\begin{aligned}
c^{0}= & (1-\beta)\left(a_{t}-b_{t}\right)+(1-\beta) \sum_{s=0}^{n-1} \beta^{s} y\left(1-\psi\left(\tau^{0}\right)^{2}\right)-(1-\beta) \sum_{s=0}^{n-1} \beta^{s} g^{0} \\
& +\beta^{n}\left(q y \left(1-\psi\left(\tau^{0}\right)^{2}+(1-q) y\left(1-\psi\left(\tau^{1}\right)^{2}\right)-\beta^{n}\left(q g^{1}+(1-q) g^{0}\right)\right.\right. \\
= & (1-\beta)\left(a_{t}-b_{t}\right)+y\left(1-\psi\left(\tau^{0}\right)^{2}\right)-g^{0} \\
& -\beta^{n}\left((1-q) y\left(\psi\left(\tau^{1}\right)^{2}-\psi\left(\tau^{0}\right)^{2}\right)+\beta^{n}\left(q\left(g^{0}-g^{1}\right)\right.\right.
\end{aligned}
$$

Pre-consolidation consumption takes account of the accumulation of government debt in the $n$ periods before consolidation and also attaches probability weights to the types of consolidation that will ultimately emerge. The current consumption gain (loss) from an anticipated government spending- (tax-) based consolidation is clear. These expectations drive current consumption and, therefore, current saving behavior: to the extent that agents anticipate a future cut in government spending, current consumption will rise; if they fear a future rise in taxes, current consumption will fall. While the magnitude of the realized spending cuts or tax increases is unaffected by the these expectations - since they do not affect debt dynamics prior to the consolidation - the accumulation of net foreign assets is affected. Combining the government's and households' flow budget constraints, prior to the 
fiscal consolidation, net foreign assets evolve according to,

$$
\beta\left(a_{t+1}-b_{t+1}\right)=a_{t}-b_{t}+y\left(1-\psi\left(\tau^{0}\right)^{2}\right)-c^{0}-g^{0}
$$

Substituting for the pre-consolidation level of consumption yields,

$$
\left(a_{t+1}-b_{t+1}\right)-\left(a_{t}-b_{t}\right)=\beta^{n-1}\left[(1-q) y \psi\left(\left(\tau^{1}\right)^{2}-\left(\tau^{0}\right)^{2}-q\left(g^{0}-g^{1}\right)\right]\right.
$$

and the accumulated change in net foreign assets between $t$ and $t+n$ is,

$$
\left(a_{t+n}-b_{t+n}\right)-\left(a_{t}-b_{t}\right)=\beta^{n-1} \sum_{s=0}^{n-1}\left[(1-q) y \psi\left(\left(\tau^{1}\right)^{2}-\left(\tau^{0}\right)^{2}-q\left(g^{0}-g^{1}\right)\right]\right.
$$

When the expected deadweight losses from the tax increase, $(1-q) y \psi\left(\left(\tau^{1}\right)^{2}-\left(\tau^{0}\right)^{2}\right.$, are greater than the expected cut in government spending, $q\left(g^{0}-g^{1}\right)$, households accumulate net foreign assets in anticipation of the deadweight losses to come. Since these expectations are formed over the relative probabilities of each type of consolidation, households will accumulate more (less) net foreign assets when they anticipate that the consolidation will be tax (spending)-based.

When a spending-based consolidation is realized, the jump in consumption is

$$
\begin{aligned}
c^{\text {spending }}-c^{0}= & (1-\beta)\left(\left(a_{t+n}-b_{t+n}\right)-\left(a_{t}-b_{t}\right)\right)+g^{0}-g^{1} \\
& +\beta^{n}\left((1-q) y\left(\psi\left(\tau^{1}\right)^{2}-\psi\left(\tau^{0}\right)^{2}\right)-q\left(g^{0}-g^{1}\right)\right)
\end{aligned}
$$

which will exceed the cut in government expenditure and be classed as expansionary whenever

$$
c^{\text {spending }}-c^{0}>g^{0}-g^{1}
$$

This requires,

$$
\beta^{n-1}\left[(1-q) y\left(\psi\left(\tau^{1}\right)^{2}-\psi\left(\tau^{0}\right)^{2}\right)-q\left(g^{0}-g^{1}\right)\right]>0
$$

Condition (21) implies an expansionary outcome upon the realization of a spending-based consolidation whenever,

$$
(1-q) y\left(\psi\left(\tau^{1}\right)^{2}-\psi\left(\tau^{0}\right)^{2}\right)>q\left(g^{0}-g^{1}\right)
$$

Condition (22) requires the expected size of tax distortions (not the tax revenues themselves) to exceed the expected size of the government expenditure cut, which reflect economic agents' views about the relative probability of each type of consolidation. Any delay in consolidation 
raises the required increases in tax revenues or cuts in expenditure because we are assuming that the government's finances are on an unsustainable path initially. Since the deadweight losses are non-linearly increasing in the tax rate, the deadweight losses associated with tax increases will be rising faster than the equivalent cuts in expenditure.

To conclude, fiscal consolidations are more likely to be expansionary when they have been long delayed, and when economic agents were expecting them to be tax-based with high deadweight loss but the realized consolidation is spending-based. Conversely, the biggest consumption declines from consolidation occur when the consolidation is tax-based and economic agents were expecting cuts in government spending. We explore the quantitative importance of uncertainty over the timing and composition of fiscal consolidations in a fullyfledged DSGE model below. Our experiments will differ from this simple example in a crucial respect: in line with the data, we consider temporary consolidations rather than permanent ones.

\section{Quantitative Model of Fiscal Consolidation}

We now turn to study the macroeconomic consequences of uncertain fiscal consolidations in a richer and more plausible environment. Since debt service costs are particularly important in determining debt dynamics at high debt levels, we consciously use a conventional new Keynesian model of the kind typically used to explore monetary and fiscal policy interactions, modified by allowing occasional fiscal consolidations. The consolidations are triggered after debt rises to a level that breaches a stochastic "fiscal limit." The fiscal limit is the maximum level of debt the government is able to support, which is constrained by tax Laffer curve and the realizations of shocks. Households anticipate that the government will attempt to stabilize debt through fiscal consolidations in advance of reaching this limit. Political factors such as a war of attrition over who bears the costs of a particular consolidation, however, may induce the government to leave consolidation to the last minute. ${ }^{6}$ In accord with this evidence, the probability of a fiscal consolidation in the model rises with the government debt-GDP ratio.

We also allow periodically explosive lump-sum transfers. Aside from being a feature of the data, temporarily explosive transfers allows for plausible transition from relatively low to very high debt levels. This assumption also changes the distribution of fiscal limits and, therefore, the likelihood of fiscal consolidation at a given debt level. Bi (2011) shows that possible explosive transfers can significantly lower expected future fiscal surpluses, which generates a more dispersed distribution of fiscal limits and makes it more likely the economy

\footnotetext{
${ }^{6}$ Alesina, Ardagna, and Trebbi (2006) find that political factors play a significant role in determining when a consolidation is instigated, consistent with war-of-attrition effects.
} 
will hit its fiscal limit at low levels of debt.

Households in our economy supply labor to intermediate goods producing firms with Rotemberg-style price adjustment. Their labor and profit income are taxed. The setup delivers a rich set of monetary and fiscal policy interactions. Monetary policy has real effects due to the price stickiness, which affects both the size of the tax base and real debt service costs. Fiscal policy, in the form of tax or government spending changes, not only has the usual fiscal consequences, but also influences inflation either through the labor supply response to distortionary taxation or the aggregate demand effect of changes in government spending. As a result, there will be resource costs resulting from the inflationary consequences of fiscal consolidations so that the distortions governing the calculus of consolidations go beyond the usual deadweight losses of distortionary taxation.

4.1 Housenolds The cashless economy is populated by a large number of identical households of size 1, who have preferences given by,

$$
E_{0} \sum_{t=0}^{\infty} \beta^{t} u\left(c_{t}, n_{t}\right)
$$

where $\beta \in(0,1)$ is the households' subjective discount factor, $c_{t}$ is consumption and $n_{t}$ the households' labor supply. The household receives nominal wages $\left(W_{t}\right)$ and monopoly profits $\left(\Upsilon_{t}\right)$ from the firm, both of which are taxed at the rate $\tau_{t}$, and lump-sum transfers $\left(z_{t}\right)$ from the government. The household chooses consumption, hours worked, and nominal bond holdings $\left(B_{t}\right)$ to maximize utility subject to their budget constraint,

$$
P_{t} c_{t}+\frac{B_{t}}{R_{t}}=B_{t-1}+\left(1-\tau_{t}\right)\left(W_{t} n_{t}+P_{t} \Upsilon_{t}\right)+P_{t} z_{t}
$$

The maximization problem yields the typical first-order conditions,

$$
\begin{aligned}
\frac{1}{R_{t}} & =\beta E_{t} \frac{u_{c}(t+1)}{u_{c}(t)} \frac{1}{\pi_{t+1}} \\
-\frac{u_{n}(t)}{u_{c}(t)} & =w_{t}\left(1-\tau_{t}\right)
\end{aligned}
$$

where $\pi_{t} \equiv P_{t} / P_{t-1}$ is the inflation rate and $w_{t} \equiv W_{t} / P_{t}$ is the real wage. Labor income is taxed so that changes in the tax rate will influence households' desire to work.

4.2 Final Goods Production Final goods production is for the purposes of private and public consumption. Competitive final goods firms buy the differentiated products produced by intermediate goods producers to construct consumption aggregates, which have the usual 
CES form,

$$
y_{t}=\left(\int_{0}^{1} y_{t}(i)^{\frac{\theta-1}{\theta}} d i\right)^{\frac{\theta}{\theta-1}}
$$

where $y_{t}$ is aggregate output, $y_{t}(i)$ the output of intermediate good firm $i$, and $\theta>1$ is the elasticity of demand for each firm's product. The cost minimization for final goods producers results in the demand curve for intermediate good $i$,

$$
y_{t}(i)=\left(\frac{p_{t}(i)}{P_{t}}\right)^{-\theta} y_{t}
$$

and an associated price index for final goods,

$$
P_{t}=\left(\int_{0}^{1} p_{t}(i)^{1-\theta} d i\right)^{\frac{1}{1-\theta}}
$$

4.3 Intermediate Goods Production The imperfectly competitive intermediate goods firms are subject to Rotemberg adjustment costs that penalize large price changes in excess of steady-state inflation rates. Price adjustment costs render the firm's problem dynamic,

$$
\begin{array}{ll}
\max & \sum_{t=0}^{\infty} R_{0, t}\left(p_{t}(i) y_{t}(i)-m c_{t} P_{t} y_{t}(i)-\frac{\phi}{2}\left(\frac{p_{t}(i)}{p_{t-1}(i)} \frac{1}{\pi}-1\right)^{2} P_{t} y_{t}\right) \\
\text { s.t. } & y_{t}(i)=\left(\frac{p_{t}(i)}{P_{t}}\right)^{-\theta} y_{t}
\end{array}
$$

where $m c_{t}=w_{t} / A_{t}$ is the real marginal cost implied by a linear production function, $y_{t}(i)=$ $A_{t} n_{t}(i)$. Productivity $\left(A_{t}\right)$ is common to all firms. The first-order condition, after imposing symmetry across firms, is,

$$
(1-\theta)+\theta m c_{t}-\phi\left(\frac{\pi_{t}}{\pi}-1\right) \frac{\pi_{t}}{\pi}+\beta \phi E_{t} \frac{u_{c}(t+1)}{u_{c}(t)}\left(\frac{\pi_{t+1}}{\pi}-1\right) \frac{\pi_{t+1}}{\pi} \frac{y_{t+1}}{y_{t}}=0
$$

which represents the non-linear new Keynesian Phillips curve (NKPC) under Rotemberg pricing. It would, upon linearization, correspond to the standard NKPC under Calvo (1983) pricing.

The associated monopoly profit, which is taxed by the government when received by households, is,

$$
\Upsilon_{t}=y_{t}-m c_{t} Y_{t}-\frac{\phi}{2}\left(\frac{\pi_{t}}{\pi}-1\right)^{2} y_{t}
$$


The aggregate resource constraint is,

$$
c_{t}+g_{t}=A_{t} n_{t}\left(1-\frac{\phi}{2}\left(\frac{\pi_{t}}{\pi}-1\right)^{2}\right)
$$

4.4 Monetary And Fiscal Policy The government budget constraint is,

$$
\frac{B_{t}}{R_{t}}+\tau_{t}\left(W_{t} n_{t}+P_{t} \Upsilon_{t}\right)=B_{t-1}+P_{t} g_{t}+P_{t} z_{t}
$$

While fiscal policy in the form of tax, transfers and government spending changes will obviously affect debt dynamics, monetary policy will also have a role to play, especially when debt stocks are large.

Monetary policy follows a simple inflation-targeting rule,

$$
R_{t}-R=\alpha\left(\pi_{t}-\pi\right)
$$

where $\pi$ is the target inflation rate. In a deterministic steady state, $R_{t}=R$ and $\pi_{t}=\pi$.

Before considering consolidation episodes, we describe fiscal policy variables during normal times, when no consolidation is underway. Fiscal transfers evolve exogenously, but their process depends on a regime-switching index $r s_{t}^{z}$,

$$
z\left(r s_{t}^{z}\right)= \begin{cases}\left(1-\rho^{z}\right) z+\rho^{z} z_{t-1}+\varepsilon_{t}^{z} & \text { if } r s_{t}^{z}=1\left(\rho^{z}<1\right) \\ \zeta^{z} z_{t-1}+\varepsilon_{t}^{z} & \text { if } r s_{t}^{z}=2\left(\zeta^{z}>1\right)\end{cases}
$$

with $\varepsilon_{t}^{z} \sim$ i.i.d. $\mathcal{N}\left(0, \sigma_{z}^{2}\right)$ and $r s_{t}^{z}$ following a transition matrix of $\left(\begin{array}{cc}p_{1}^{z} & 1-p_{1}^{z} \\ 1-p_{2}^{z} & p_{2}^{z}\end{array}\right)$. The Markov regime-switching process moves from a stationary process with $\rho^{z}<1$ to one where transfers explode with $\zeta^{z}>1$. There can be prolonged periods during which transfer increases leading to sustained increases in government debt, which can prompt attempts at fiscal consolidation. Periodic instability in transfers is common to many advanced economies and, as the International Monetary Fund (2009) reports, are likely to become more widespread as populations age.

In normal times, government spending follows an $A R(1)$ process,

$$
g_{t}-g=\rho^{g}\left(g_{t-1}-g\right)+\varepsilon_{t}^{g} \quad \varepsilon_{t}^{g} \sim i . i . d . \mathcal{N}\left(0, \sigma_{g}^{2}\right)
$$

and tax rates adjust to stabilize government debt with $\gamma^{\tau}>0$,

$$
\tau_{t}-\tau=\gamma^{\tau}\left(b_{t-1}-b\right)+\varepsilon_{t}^{\tau}
$$




\section{Fiscal Limit and Fiscal Consolidation}

This section describes the computation of the model's fiscal limit, which forms the basis for the government's timing of undertaking a fiscal consolidation.

5.1 Distribution of the Fiscal Limit Laffer curves provide a natural starting point for quantifying the fiscal limit from the tax revenue side of the government's budget constraint. At the peak of the Laffer curve, tax revenues reach their maximum and, for a given level of total government expenditures, the present value of primary surpluses is maximized. Revenues, expenditures, and discount rates, of course, vary with the shocks hitting the economy, generating a distribution for the maximum debt-GDP level that can be supported. This produces the distribution of the fiscal limit.

To compute the fiscal limit, we assume that the monetary authority keeps the inflation rate at its target $\left(\pi_{t}=\pi\right)$, so the peak of the Laffer curve is a function of the exogenous state of the economy $\left(A_{t}, g_{t}\right)$.

$$
\begin{aligned}
\tau_{t}^{\max } & =\tau^{\max }\left(A_{t}, g_{t}\right) \\
T_{t}^{\max } & =\mathcal{T}^{\max }\left(A_{t}, g_{t}\right)
\end{aligned}
$$

where the function $\tau^{\max }\left(\mathcal{T}^{\max }\right)$ maps the state into the tax rate (revenues) at the peak. Evidently, the stochastic processes governing the exogenous states induce stochastic processes for both the tax rate that maximizes revenues and the maximum level of revenues.

The fiscal limit is defined, following Bi (2011), as the discounted sum of expected maximum primary surpluses in all future periods.

$$
\mathcal{B}^{*}=E \sum_{t=0}^{\infty} \beta^{t} \underbrace{\beta_{p}}_{\text {political factor }} \frac{u_{c}^{\max }\left(A_{t}, g_{t}\right)}{u_{c}^{\max }\left(A_{0}, g_{0}\right)} \underbrace{\left(\mathcal{T}^{\max }\left(A_{t}, g_{t}, z_{t}, r s_{t}^{z}\right)-g_{t}-z_{t}\right)}_{s_{t}^{\max }}
$$

The stochastic discount factor is obtained when tax rates are at the peak of the Laffer curve, $\beta^{t} u_{c}^{\max }\left(A_{t}, g_{t}\right) / u_{c}^{\max }\left(A_{0}, g_{0}\right)$, but modified to allow for a political risk parameter $\beta_{p}$. Higher political risk - lower $\beta_{p}$-lends itself to multiple interpretations that reflect the private sector's beliefs about policy. Most straightforward is the idea that policymakers have effectively shorter planning horizons than the private sector, see Acemoglu, Golosov, and Tsyvinski (2008). To see this, rewrite the discount factor in $(38)$ as $\left(\beta_{p} \beta\right)^{t} /\left(\beta_{p}\right)^{t-1}$, so that a lower value of $\beta_{p}$ reduces the present value of maximum surpluses. An alternative interpretation is that implies that private agents place probability mass on both the maximum surpluses $\left(s^{\max }\right)$ and on zero primary surpluses. Rewrite the surpluses as $\beta_{p} s^{\max }+\left(1-\beta_{p}\right) \cdot 0$ 
for this interpretation. Nothing we do hinges on the precise interpretation attached to $\beta_{p}$. As a practical matter, setting $\beta_{p}<1$ serves to shift down the distribution of the fiscal limit, which generates occurrences of fiscal consolidations at lower levels of debt similar to those observed in the data. Moreover, as discussed in section 4, the possibility of temporarily explosive transfers leads to a wider dispersion of the fiscal limit, which also creates the possibility of consolidations at relatively low debt levels.

Since there exists a unique mapping between the exogenous state space, $\left(A_{t}, g_{t}, z_{t}, r s_{t}^{z}\right)$, and $\tau_{t}^{\max }$ and $T_{t}^{\max }$, the unconditional distribution of the fiscal limit, $f\left(\mathcal{B}^{*}\right)$, can be derived from a Markov Chain Monte Carlo simulation following the steps in appendix A.

5.2 Fiscal Policy During Consolidations We modify the government spending process and the tax rule as,

$$
\begin{aligned}
& g_{t}-g=-m_{t}^{g}+\rho^{g}\left(g_{t-1}-g\right) \\
& \tau_{t}-\tau=m_{t}^{\tau}+\gamma^{\tau}\left(b_{t-1}-b\right)
\end{aligned}
$$

Fiscal consolidations take the form non-zero values for the intercept terms $m_{t}^{g}$ and $m_{t}^{\tau}$, implying reductions in government spending and increases in taxation.

At each period $t$, the effective fiscal limit $\left(b_{t}^{*}\right)$ is drawn from the distribution of the fiscal limit. We treat the choice of $b_{t}^{*}$ as random, being driven by policymakers' perceived costs of fiscal consolidation. If the existing debt level $\left(b_{t-1}\right)$ surpasses the effective fiscal limit, the government undertakes a consolidation that lasts for four periods - in line with AA's dataeither through raising the tax rate (with probability $\omega$ ) or cutting government purchases (with probability $1-\omega$ ); otherwise, the government follows the usual fiscal policy rules that set $m_{t}^{\tau}=m_{t}^{g}=0$.

A state variable $r s_{t}$ tracks the path of fiscal consolidations: it equals 1 in normal times; if the government undertakes a tax-based consolidation, $r s_{t}$ switches to 2 and the consolidation lasts for another 3 periods, so $r s_{t+1}=3, r s_{t+2}=4, r s_{t+3}=5$, before returning to the normal no-consolidation state; if the government undertakes a spending-based consolidation at $t$ that lasts 4 periods, $r s_{t}=6, r s_{t+1}=7, r s_{t+2}=8, r s_{t+3}=9$, before exiting. ${ }^{7}$ These policy dynamics are summarized by,

\footnotetext{
${ }^{7}$ After a consolidation, policy stays in the no-consolidation state for at least one period before another consolidation can occur.
} 


$$
\begin{cases}\text { if } b_{t-1}<b_{t}^{*}: & \text { no consolidation }\left(r s_{t}=1, m_{t}^{\tau}=m_{t}^{g}=0\right) \\ \text { otherwise, with prob of } \omega: & \text { tax-based consolidation }\left(r s_{t} \ldots r s_{t+3}=2, \ldots, 5\right) \\ & \left(m_{t}^{\tau}=m^{\tau}, m_{t}^{g}=0\right) \\ \text { with prob of } 1-\omega: & \text { spending-based consolidation }\left(r s_{t} \ldots r s_{t+3}=6, \ldots, 9\right) \\ & \left(m_{t}^{\tau}=0, m_{t}^{g}=m^{g}\right)\end{cases}
$$

Even though the households know the distribution of the fiscal limit, the timing and the composition of consolidation are uncertain.

\section{Calibration and Solution}

The model is calibrated at a quarterly frequency to EU-14 data. We focus on those economies because they feature heavily in the AA dataset, both in terms of undertaking the sizeable fiscal consolidations and of occasionally enjoying consolidations that AA labelled as "expansionary."

We calibrate fiscal parameters to match average EU-14 data from 1971 to $2007 .{ }^{8}$ In steady state, government purchases are 21 percent of GDP, lump-sum transfers are 18 percent of GDP, and the tax rate is 0.41 , implying a steady-state government debt-GDP ratio of 50.38 percent. The tax adjustment parameter $(\gamma)$ is calibrated to 0.5 at an annual rate, which is close to the average of estimates in EU-14. The regime-switching parameters $p_{1}^{z}$ and $p_{2}^{z}$ are calibrated to 0.975 , so that the average length of each regime is 10 years. A higher $p^{z}$ leads to a more dispersed distribution of fiscal limits. $\zeta^{z}$ is set at 1.003 , implying an increase of 12.75 percent in transfers in 10 years. The shock processes for $z_{t}$ and $g_{t}$ are estimated using linearly detrended data, as summarized in Table 2.

As discussed in section 2, the length of consolidations is calibrated to one year, while the size of consolidations, the $m^{\tau}$ and $m^{g}$ terms, are calibrated to 1 percent of the steady-state level of GDP. The International Country Risk Guide's (ICRG) index of political risk offers one way to calibrate the political factor $\left(\beta_{p}\right)$, see Arteta and Galina (2008). The average ICRG index of EU-14 was 85 out of 100 during the period of 1984-2009.

The household discount rate is 0.99 and the net real interest rate is 4.04 percent at annual rate. The utility function is $u(c, n)=\log c+\chi_{n} \log (1-n)$. The leisure preference parameter $\left(\chi_{n}\right)$ is calibrated so that the household spends 25 percent of its time working at the steady state and the Frisch elasticity of labor supply is 3. Time endowment and the productivity level at the steady state are normalized to 1 . Productivity remains at the steady state. ${ }^{9}$ The price elasticity of demand $(\theta)$ is assumed to be 11 and the Rotemberg adjustment parameter

\footnotetext{
${ }^{8}$ Appendix B describes the data.

${ }^{9}$ Stochastic productivity significantly increases the computational time but does not change the results.
} 
$(\phi)$ is 100 , which is equivalent to Calvo-type overlapping contracts models where 26.7 percent of the firms reoptimize each quarter, see Keen and Wang (2007). The gross inflation rate is calibrated to 1.03 at annual rate and the Taylor rule parameter is assumed to be 1.5 in the benchmark case.

Under this calibration, the distribution of the fiscal limit can be simulated by drawing from the distributions of the exogenous shocks. Figure 1 reports the kernel-estimated cumulative distribution of the fiscal limit. Along an equilibrium path, as the debt rises, so too does the probability that debt will exceed the effective fiscal limit, $b_{t}^{*}$, drawn from the distribution in the figure. The fat tail is generated by the possibility of entering the explosive transfers regime.

We solve the full non-linear model laid out in section 4, coupled with the fiscal limit described in section 5, using the monotone map method. The solution method, based on Coleman (1991) and Davig (2004), discretizes the state space and conjectures candidate decision rules that reduce the system to a set of first-order expectational difference equations. Decision rules map the state at period $t$ into the stock of government debt, the real wage, and the inflation rate in the same period. Given the state denoted as $\psi_{t}=\left\{b_{t-1}, g_{t}, z_{t}, \tau_{t}, r s_{t}, r s_{t}^{z}\right\}$, the mappings can be written as $b_{t}=f^{b}\left(\psi_{t}\right), w_{t}=f^{w}\left(\psi_{t}\right), \pi_{t}=f^{\pi}\left(\psi_{t}\right)$. After finding the decision rules, we solve for the bond-pricing rule, $q_{t}=f^{q}\left(\psi_{t}\right)$, using the government budget constraint. The interest rate on government bonds can also be solved using $R_{t}=1 / q_{t}$, denoted as $f^{R}\left(\psi_{t}\right)$. Appendix $\mathrm{C}$ describes the nonlinear solution method.

\section{Fiscal Consolidation: Time Uncertainty Only}

As section 2 describes, fiscal consolidations can occur across a wide range of debt-GDP ratios, but it is reasonable to posit that the probability of a fiscal consolidation is rising in the debt-GDP ratio. Consolidations at low debt levels are more likely to be something of a surprise, than the consolidations following sustained increases in debt. We focus initially on uncertainty over the timing and duration of consolidations.

7.1 Tax-Based Fiscal Consolidation Tax-based consolidations, labelled as $r s_{t}^{\tau}$, are specified as,

$$
r s^{\tau}: \quad \tau_{t}-\tau=m^{\tau}\left(r s_{t}\right)+\gamma^{\tau}\left(b_{t-1}-b\right)
$$

Fiscal consolidation measurement $\left(m^{\tau}\right)$ depends on the state-dependent variable $r s_{t}$, which in turn hinges on equilibrium government liabilities $b_{t-1}$ and the stochastic fiscal limit $b_{t}^{*}$. With consolidations lasting four periods, the regime change is governed by, 


$$
\begin{cases}\text { if } b_{t-1}<b_{t}^{*}: & r s_{t}=1 ; m_{t}^{\tau}=0 \\ \text { otherwise: } & r s_{t} \ldots r s_{t+3}=2, \ldots, 5 ; m_{t}^{\tau}=m^{\tau}\end{cases}
$$

If government debt exceeds the stochastic fiscal limit, $b_{t}^{*}$, it implements a consolidation for one year by raising taxes beyond the level implied by the usual fiscal rule in an attempt to reduce government debt. To draw out the role of expectations, we contrast $r s^{\tau}$ consolidations to the same-sized consolidations implemented through a sequence of unanticipated i.i.d. policy shocks $\varepsilon_{t}^{\tau}$, labeled as "no-RS".

$$
\text { no-RS: } \quad \tau_{t}-\tau=\gamma^{\tau}\left(b_{t-1}-b\right)+\varepsilon_{t}^{\tau}
$$

Expectations play a central role in determining the macroeconomic impacts of consolidation. When consolidation entails a regime switch, agents know the new policy rules remain in effect for four periods and, therefore, adjust their expectations accordingly. A sequence of surprise policies, however, has no effect on decision rules. Figure 2 compares the impulse responses from the no-RS (dotted lines) and the $r s^{\tau}$ (solid lines) cases when the initial expected probability of fiscal consolidation is only 0.08 . The figure plots macro variables, the difference in the outcome under a fiscal consolidation relative to that without consolidation, as percentage of the steady-state level. With a low probability, the consolidation comes as a surprise in both cases.

In the $r s^{\tau}$ case, once the fiscal consolidation begins, economic agents know that taxes will remain high for four quarters, raising real wages and marginal costs. Firms raise prices in anticipation of this sustained rise in marginal costs; inflation jumps up and gradually declines over the course of the consolidation. While the initial jump helps deflate the real value of government debt, the active monetary policy raises real interest rates in response to the rise in inflation, offsetting some of the debt reduction. In the no-RS case, consolidations arrive as i.i.d. shocks. Price-setters are repeatedly surprised by the sustained increase in marginal costs and inflation. Active monetary policy does not raise real interest rates by as much and the repeated inflation surprises drive a wedge between ex-ante and ex-post real interest rates, making the consolidation more effective in stabilizing debt. The uncertainty over the duration of fiscal consolidations may affect their likelihood of success.

A more interesting channel for expectations arises from the likelihood of consolidations. The probability of a regime-change consolidation is small at low-debt levels, and if a consolidation does occur, it surprises agents. At high levels of debt, on the other hand, a consolidation is to some extent anticipated. Such expectations affect economic behavior in the pre-consolidation periods, and the consolidation itself can have relatively small effects when it is actually realized. 
Figure 3 repeats the same experiment as in figure 2 but with the debt-GDP ratio at 160 percent, which raises the probability of fiscal consolidation to 0.82 . When a consolidation is expected but has not yet arrived, it generates negative inflation surprises, which worsen debt dynamics under an active monetary policy. As a result, when the fiscal consolidation is realized, its relative impact is not as great as it would have been if the consolidation had been unanticipated. But the marginal impact on debt is now reversed: removing the uncertainty of the consolidation duration removes the large negative inflation surprises coming with the no consolidation base case. Since these surprises are acting on a very large stock of debt, removing the uncertainty facilitates stabilizing debt. This reverse highlights the importance of expectations over the likelihood and duration of fiscal consolidations.

To understand inflation dynamics and the nature of the surprises induced by fiscal consolidations, we plot the level of inflation and expected inflation in figure 4 when the initial debt is low or high. The inflation rate (dotted-circle) and one-step-ahead expected inflation $E_{t-1} \pi_{t}$ (dashed-circle) are plotted in the top panel of figure 4, in which the debt jumps to 80 percent of GDP at $t=5$ and the probability of consolidation climbs to 0.08 , but no fiscal consolidation ever occurs. The tax rate rises with the jump in debt level, raising marginal costs and inflation. As the debt is gradually stabilized over time, tax rates fall and inflation returns to its steady-state value. The triangle lines show the paths of $\pi_{t}$ and $E_{t-1} \pi_{t}$ when a fiscal consolidation does occur at $t=9$. The tax rate rises, labor supply contracts and consumption falls. Higher marginal costs further raise inflation and, since the consolidation was unexpected, there is an inflation surprise in the first period of the consolidation.

If the debt jumps to 120 percent of GDP at $t=5$ and the probability of fiscal consolidation rises to 0.82 , shown in the bottom panel, inflationary expectations rise significantly after the debt rises, even if no actual consolidation takes place. Actual inflation, on the other hand, mimics the path in the top panel. When consolidation does occur at $t=9$, taxes and inflation rise, creating a positive inflation surprise. There is no inflation surprise during the consolidation or in the period immediately following the exit, as economic agents know that there will be no further fiscal consolidation for at least one period. In all other periods, there is a non-zero probability attached to consolidation, creating an ongoing inflation surprise.

7.2 Spending-Based Fiscal Consolidations We now consider government spendingbased consolidations $\left(r s^{g}\right)$, which are specified as,

$$
r s^{g}: \quad g_{t}-g=-m^{g}\left(r s_{t}\right)
$$

When government debt exceeds the stochastic fiscal limit, $b_{t}^{*}$, the government cuts its spending by $m^{g}\left(r s_{t}\right)$ for one year. We contrast this $r s^{g}$ model with the same-sized consolidations 
implemented through a sequence of unanticipated i.i.d. policy shocks (which we label the no-RS model),

$$
\text { no-RS: } g_{t}-g=\varepsilon_{t}^{g}
$$

Figure 5 compares the impulse responses from no-RS and $r s^{g}$ models when the expected probability of fiscal consolidation is low. Once a consolidation begins, price-setters expect it to last for a year in $r s^{g}$ model, and inflation falls immediately and then slowly returns to base. With an active monetary policy, a lower inflation leads to lower real interest rates, which helps to reduce debt service costs and maintain the size of the tax base. In contrast, in the no-RS model, during the consolidation price-setters fail to anticipate the subsequent decreases in government spending and inflation doesn't fall by as much on impact.

Uncertainty over the duration of a spending-based consolidation reduces its deflationary consequences, contrasting with tax-based consolidations, where the duration uncertainty was less inflationary and raised debt service costs by less.

Figure 6 considers the same experiments except that the probability of consolidation is high. In the $r s^{g}$ model, economic agents anticipate that government spending cuts are imminent, and the no-consolidation base case contains positive inflation surprises as consolidations are expected but not realized. Outcomes are quite similar to those under lower debt levels. One noticeable difference is that there is a smaller increase in consumption when the consolidation is realized, as households were already expecting government spending to be cut. Similarly, the initial deflation is smaller as it was already factored into inflation expectations. ${ }^{10}$

7.3 Key Message of Time Uncertainty Output multipliers are a convenient way to summarize differences across the no-RS, $r s^{\tau}$ and $r s^{g}$ policy scenarios. The multipliers are computed as,

$$
\text { Multiplier } \quad \Gamma_{t+k}^{y}=\frac{\sum_{j=0}^{k}\left(\prod_{i=0}^{j} r_{t+i}^{-1}\right)\left(y_{t+j}^{\text {shock }}-y_{t+j}^{n o}\right)}{\sum_{j=0}^{k}\left(\prod_{i=0}^{j} r_{t+i}^{-1}\right)\left(x_{t+j}^{\text {shock }}\right)}
$$

where $r_{t}$ is the real interest rate, and $x$ denotes the type of fiscal adjustment: $x_{t}=\tau_{t} y$ for taxbased and $=-g_{t}$ for spending-based consolidations. It measures the discounted percentage change in cumulative output for one discounted unit of fiscal consolidation measure.

Figure 7 shows that at relatively low levels of initial debt, i.i.d. tax and government spending consolidations provide upper and lower bounds for the same-sized consolidations of a known duration. Not knowing the duration of the consolidation limits the inflation-

\footnotetext{
${ }^{10}$ The spike in inflation expectations upon exiting from the consolidation reflects the fact that economic agents are expecting a deflationary consolidation in the no-consolidation base case, while in the period following a realized consolidation they know that no consolidation will take place for at least one period.
} 
ary (deflationary) response to the tax (spending)-based fiscal consolidation which, in turn, affects the extent to which monetary policy raises (reduces) real interest rates during the consolidation. In contrast, at high-debt levels, tax-based consolidations of known duration outperform those of uncertain duration, while government spending-based consolidations perform in a similar way regardless of the duration uncertainty. The expansionary effect from $r s^{\tau}$ is due to the fact that the tax increase today reduces the need for future tax increases, which would otherwise have negative effects on current debt service costs and the tax base. This is consistent with the expectation effects highlighted in the simple model of section 3 .

\section{Fiscal Consolidation: Time and Composition Uncertainty}

In practice, fiscal consolidations are uncertain both in their timing and their composition. We now consider the two sources of uncertainty jointly using the policy rules sketched in section 5.2. Consolidation intercepts, $m_{t}^{\tau}$ and $m_{t}^{g}$, depend on the state variable $r s_{t}$, such that whenever the level of government liabilities exceeds the stochastic fiscal limit, a fiscal consolidation is triggered and lasts for one year, which involves tax increases with probability $\omega$, and government spending cuts with probability $(1-\omega)$. We calibrate the consolidations as $m^{\tau}=0.01$ and $m^{g}=0.01 y$, which delivers tax- and spending-based consolidations of 1 percent of GDP.

8.1 Benchmark Case: $\omega=0.75$ And $\alpha=1.5$ In line with the AA data, the probability $\omega$ is calibrate to 0.75 , implying that the probability of a tax-based consolidation is threetimes that of a government spending-based consolidation. Setting $\alpha=1.5$ makes monetary policy actively combat inflation in the manner that Taylor (1993) suggests.

Figure 8 compares the impulse responses for the two types of consolidations when the initial probability of fiscal consolidation is low. There are few expectation effects beyond the fact that when a consolidation occurs, economic agents know it will last for one year. If the fiscal consolidation turns out to be tax-based, the impulse responses are very similar to those observed when tax-based consolidations are the only possible type [figure 2]. Similarly, when the consolidation is essentially unexpected, if the realized consolidation cuts government spending, then the impulse responses are very similar to the outcomes of consolidations when spending is the only possible type [figure 5]. When the probability of fiscal consolidation is low, economic agents do not expect there to be a consolidation of any kind, so uncertainty over the type is not important.

In figure 9, government debt is high and agents believe a fiscal consolidation is imminent. Now uncertainty over which type of consolidation will be realized starts to matter. Agents 
place 0.75 probability on tax increases, anchoring their expectations on inflationary increases in distortionary taxation when the consolidation begins. If a spending-based consolidation occurs, it surprises agents and reduces inflation relative to the no-consolidation case, which incorporates expectations of predominately tax-based consolidations even though they are not realized. The deflationary government spending-based consolidation, together with active monetary policy, reduces real interest rates, raising the tax base and reducing debt service costs. Consumption rises significantly from realizing the government spending consolidation when households were worried that the consolidation would be tax-based. Real wages rise relative to the no-consolidation case, though they would have fallen if there were no composition uncertainty and all consolidations were spending-based.

When the realized consolidations are of the tax-based type, the results are qualitatively similar to those seen when all consolidations are tax-based without any composition uncertainty, since these were largely anticipated. Higher distortionary tax rates during the fiscal consolidation raise marginal costs and inflation during the course of the consolidation. Active monetary policy responds to the higher inflation by raising real interest rates, which diminishes the tax base and raises debt service costs. This accounts for the relatively poor performance of the tax-based consolidations in stabilizing debt when debt levels are high, even although both tax and spending based consolidations have roughly the same impact on the primary deficit.

Figure 10 compares the output multiplier under tax- and spending-based consolidations when the type of consolidation is uncertain, and tax increase and spending cuts in the no-RS model. At low levels of debt, the two types of no-RS fiscal consolidations provide bounds for the regime-switching model, similar to the comparison with only time uncertainty in figure 7. When debt levels are high, spending-based consolidations in the regime-switching model with composition uncertainty significantly outperform the same-sized consolidations in no-RS model. On the other hand, tax-based consolidations in the model with composition uncertainty are very similar to tax increases applied in no-RS model. This is due to the expectation spill-over effect, as explained in the analytical model in section 3. When economic agents fear that a consolidation is imminent and are expecting it to be tax-based, they are relieved to find that the consolidation effort is spending-based. While the spending cuts do not lead to an immediate increase in output, they significantly reduces their short-run costs and raises the medium- to long-term benefits.

If there were never any fear of a consolidation being tax-based, these expectational effects would not apply and the discounted output multiplier from a spending-based consolidation would always be negative. In contrast, when the realized consolidation is tax-based, but there was some possibility that it could be spending-based, the output costs of the consolidation 
rise. As we shall now see, this ranking could be different depending on the monetary policy stance (via $\alpha$ ) and economic agents' expectations about the likely composition of any fiscal consolidation (via $\omega)$.

\subsection{Monetary Policy and the Household's Expectation of Consolidation}

8.2.1 Less ACtive Monetary Policy In figure 9, deflationary spending cuts facilitate relaxing monetary policy, which helps stabilize debt through its impact on the tax base and debt service costs. But when monetary policy responds to the higher inflation generated by tax-based consolidations, it raises the interest rates on government debt, which is particularly destabilizing when debt levels are high. This reasoning suggests that the responsiveness of monetary policy to inflation is critical in determining the relative efficacy of the alternative types of fiscal consolidation. At the initial debt level of 160 percent of GDP, figure 11 shows the impulse responses across the two types of fiscal consolidation where monetary policy is less active $(\alpha=1.2)$ relative to the benchmark of $\alpha=1.5$ considered in figure 9.

Contrasting the two figures, reducing the responsiveness of interest rates to inflation deepens the recession under government spending-based consolidations, and reduces its ability to stabilize debt. In contrast, tax-based consolidations are no longer thwarted by monetary policy: in fact, there is a more pronounced decline in debt following the tax-based consolidation when monetary policy is less active. Nevertheless, spending-based consolidations remain relatively more effective in reducing the debt burden, and this relative efficacy at high debt levels is likely to exist as long as monetary policy is active.

Figure 12 repeats figure 10, but with the less-active monetary policy. Tax increases become more expansionary, as the output multiplier turns to positive upon the exit of fiscal consolidation, while spending cuts are much more contractionary. In an environment when nominal interest rates are close to, or at, the zero lower bound, we are far more likely to observe economic expansions following tax-based than spending-based consolidations.

\subsubsection{Lower Probability of Tax-Based Consolidation In our final experiment,} we return to our benchmark monetary policy of $\alpha=1.5$, but reverse the relative likelihood of tax- and spending-based consolidations by setting $\omega=0.25$. Spending cuts are three-times more likely than tax increases. As before, at low-debt levels this reversal makes negligible difference since neither kind of consolidations is expected. At high-debt levels, however, consolidations are thought to be imminent and it matters which type of consolidation economic agents anticipate will occur. When we reverse the relative probabilities of tax- and spending-based consolidations, economic agents believe the consolidations will lead to deflationary cuts in government spending. 
As shown in figure 13, when the relatively low probability tax-based consolidation is realized, inflation rises relative to the no-consolidation case and monetary policy responds by raising real interest rates, reducing the tax base and fueling debt service costs. Government debt rises relative to the no-consolidation case, undermining the stabilizing effects in figure 9. Spending-based consolidations remain relatively effective in stabilizing debt, but become less expansionary than those observed in figure 9.

\section{Summary}

In this paper, we have explored the non-linearities inherent in state-dependent fiscal consolidations. The exact timing of these consolidations is uncertain, but the likelihood of observing a consolidation is rising as debt levels rise. In line with the data, we have contrasted taxbased consolidations with spending-based ones in a variety of contexts, including low- and high-debt levels, different degrees of monetary policy activism, and different beliefs about future consolidations. Our results show that there are significant interactions between all these factors in determining the marginal impact of a given fiscal consolidation. For example, both tax- and spending-based consolidations can be equally successful in stabilizing government debt at low debt levels; nevertheless, the response to the same policies can be quite different at higher debt levels when fiscal consolidations are thought to be imminent. In particular, the monetary policy response to the consolidation and any inflation it generates, along with expectations over the composition of consolidations, are important factors in determining the outcome. Undertaking a spending-based consolidation is more likely to have an expansionary effect on the economy when economic agents were anticipating a taxed-based consolidation, especially when monetary policy is actively targeting inflation.

In terms of the key policy implications of our analysis, we can draw two main conclusions. Firstly, the possibility of "expansionary" fiscal consolidations is driven by the resolution of uncertainty associated with the composition and timing of the eventual consolidations. Because the possibility of consolidation can act as a drag on economic activity, governments can enhance economic growth by removing the uncertainty as early as possible, even if doing so reduces the likelihood of observing an "expansionary" fiscal consolidation subsequently. In the context of our model, "expansionary" fiscal consolidations are unlikely to be something that governments seek, but instead reflect a failure to rule out growth-reducing policy options sooner.

Secondly, our analysis also suggests that the inflationary consequences of alternative fiscal instruments and the monetary policy response to that inflation are very important in determining the outcomes, since debt service costs are a crucial aspect of debt dynamics at high debt levels. Tax- and spending-based consolidations are fundamentally different in their 
inflation consequences, since distortionary taxation raises marginal costs and fuels inflation in a sticky-price economy, while government spending cuts are typically deflationary. These different inflation responses to debt service costs then depend on the monetary policy response to inflation. Attempting a fiscal consolidation in an environment where interest rates have reached their zero lower bound, is potentially quite different from doing so when monetary policy is facing an inflationary threat. Future research will attempt to assess whether such factors alter the optimal composition of fiscal consolidations, since, for example, the inflationary consequences of anticipated tax increases may actually be welcomed in a zero lower bound environment. More generally, we shall seek to determine the optimal combination of monetary and fiscal policies needed to implement successful fiscal consolidations. 


\section{REFERENCES}

Acemoglu, D., M. Golosov, and A. Tsyvinski (2008): "Political Economy of Mechanisms," Econometrica, 76(3), 619-642.

Alesina, A., and S. Ardagna (1998): "Tales of Fiscal Adjustments," Economic Policy, $13(27), 489-545$.

- (2010): "Large Changes in Fiscal Policy: Taxes vs Spending," Tax Policy and the Economy, 24, 35-68.

Alesina, A., S. Ardagna, and F. Trebbi (2006): "Who Adjusts and When? The Political Economy of Reforms," IMF Staff Papers, 53, 1-29.

Alesina, A., And R. Perotti (1995): "Fiscal Expansions and Adjustments in OECD Countries," Economic Policy, 10(21), 205-248.

(1997): "The Welfare State and Competitiveness," American Economic Review, 87(5), 921-939.

Ardagna, S. (2004): "Fiscal Stabilizations: When Do They Work and Why," European Economic Review, 48(5), 1047-1074.

Arteta, C., and H. Galina (2008): "Sovereign debt crises and credit to the private sector," Journal of International Economics, 74(1), 53-69.

Bertola, G., and A. Drazen (1993): "Trigger Points and Budget Cuts: Explaining the Effects of Fiscal Austerity," American Economic Review, 83(1), 11-26.

BI, H. (2011): "Sovereign Default Risk Premia, Fiscal Limits and Fiscal Policy," European Economic Review, forthcoming.

Briotti, M. G. (2005): "Economic Reactions to Public Finance Consolidation - A Survey of the Literature," European Central Bank, Occasional Paper Series, No. 38.

Coleman, Wilbur John, I. (1991): "Equilibrium in a Production Economy with an Income Tax," Econometrica, 59(4), 1091-1104.

Davig, T. (2004): "Regime-Switching Debt and Taxation," Journal of Monetary Economics, 51(4), 837-859.

Giavazzi, F., and M. Pagano (1990): "Can Severe Fiscal Contractions Be Expansionary? Tales of Two Small European Countries," NBER Macroeconomics Annual, 5, 75-111. 
International Monetary Fund (2009): "Fiscal Implications of the Global Economic and Financial Crisis," IMF Staff Position Note SPN/09/13.

(2011): "Shifting Gears: Tacking Challenges on the Road to Fiscal Adjustment," April 2011.

Keen, B. D., And Y. Wang (2007): "What is a Realistic Value for Price Adjustment Costs in New Keynesain Models?," Applied Economics Letters, 14(1), 789-793.

Lambertini, L., and J. Tavares (2005): "Exchange Rates and Fiscal Adjustments: Evidence from the OECD and Implications for the EMU," B.E. Journal of Macroeconomics, $5(1)$.

Perotti, R. (1996): "Fiscal Consolidation in Europe: Compostion Matters," American Economic Review, 86(2), 105-110.

Sutherland, A. (1997): "Fiscal Crises and Aggregate Demand: Can High Public Debt Reverse the Effects of Fiscal Policy?," Journal of Public Economics, 65(2), 147-162.

TAYlor, J. B. (1993): "Discretion versus Policy Rules in Practice," Carneige-Rochester Conference Series on Public Policy, 39(1), 195-214. 


\section{A Simulating the Fiscal Limit}

Assume the utility function is $u\left(c_{t}, n_{t}\right)=\log c_{t}+\chi_{N} \log \left(1-n_{t}\right)$. Assuming the inflation rate is its steady-state level, labor supply can be solved analytically as a function of $\left(\tau_{t}, A_{t}, g_{t}\right)$ using the first-order conditions.

$$
n_{t}=\frac{w_{t}\left(1-\tau_{t}\right)+\chi_{n} g_{t}}{w_{t}\left(1-\tau_{t}\right)+\chi_{n} A_{t}}
$$

where $w_{t}=(\theta-1) / \theta A_{t}$. The total tax revenue is $T_{t}=\left(w_{t} n_{t}+\Upsilon_{t}\right) \tau_{t}$, and the peak of Laffer curve, $\tau_{t}^{\max }$, can be solved as,

$$
\tau^{\max }\left(A_{t}, g_{t}\right)=1+\chi_{n} \frac{A_{t}}{w_{t}}-\frac{\sqrt{\chi_{n}\left(w_{t}+\chi_{n} A_{t}\right)\left(A_{t}-g_{t}\right)}}{w_{t}}
$$

The fiscal limit $\mathcal{B}^{*}$ can be obtained using Markov Chain Monte Carlo simulation:

1. First, for each simulation, we randomly draw the shocks of government purchases, and transfers for 1500 periods. Assuming that the tax rate is always at the peak of the dynamic Laffer curves, we compute the paths of all other variables using the household first-order conditions and the budget constraints. According to equation 38, we compute the discounted sum of maximum fiscal surplus by discarding the first 500 draws as a burn-in period.

2. Second, we repeat the simulation for 100,000 times and obtain the distribution of the fiscal limit, which is then approximated through kernel density estimation.

3. At each period of time, the effective fiscal limit $b_{t}^{*}$ is a random draw from the distribution.

\section{B Data Appendix}

The fiscal data is from the OECD Economic Outlook No. 84 (2009) for the period between 1971 and 2009. The sample includes Austria, Belgium, Germany, Denmark, Spain, Finland, France, Greece, Ireland, Italy, Netherlands, Norway, Sweden, and United Kingdom. The average tax rate is defined as the ratio of the total tax revenue over GDP, including social security, indirect and direct taxes. The government purchases are government final consumption of expenditures. Lump-sum transfers are defined as the sum of social security payments, net capital transfers and subsidies. 


\section{Solving the Nonlinear Model}

The decision rules for government debt $b_{t}=f^{b}\left(\psi_{t}\right)$, real wage $w_{t}=f^{w}\left(\psi_{t}\right)$ and inflation rate $\pi_{t}=f^{\pi}\left(\psi_{t}\right)$, are solved in the following steps:

1. Discretize the state space $\psi_{t}=\left\{b_{t-1}, g_{t}, z_{t}, \tau_{t}, r s_{t}, r s_{t}^{z}\right\}$ with grid points of $n_{b}=25, n_{g}=$ $5, n_{z}=5, n_{\tau}=11, n_{r s}=9, n_{r s z}=2$. Make an initial guess of the decision rules $\left(f_{0}^{b}, f_{0}^{w}, f_{0}^{\pi}\right)$ over the state space.

2. At each grid point, solve the model and obtain the updated rule $\left(f_{i}^{b}, f_{i}^{w}, f_{i}^{\pi}\right)$ using the given rule $\left(f_{i-1}^{b}, f_{i-1}^{w}, f_{i-1}^{\pi}\right)$. Other than the monetary and fiscal policy rules, the optimization equations can be summarized,

$$
\begin{aligned}
\frac{1}{R_{t}} & =\beta E_{t} \frac{u_{c}(t+1)}{u_{c}(t)} \frac{1}{\pi_{t+1}} \\
-\frac{u_{n}(t)}{u_{c}(t)} & =w_{t}\left(1-\tau_{t}\right) \\
c_{t}+\frac{b_{t}}{R_{t}} & =\frac{b_{t-1}}{\pi_{t}}+\left(1-\tau_{t}\right)\left(w_{t} n_{t}+\Upsilon_{t}\right)+z_{t} \\
c_{t}+g_{t} & =A_{t} n_{t}\left(1-\frac{\phi}{2}\left(\frac{\pi_{t}}{\pi}-1\right)^{2}\right) \\
(1-\theta)+\theta m c_{t} & =\phi\left(\frac{\pi_{t}}{\pi}-1\right) \frac{\pi_{t}}{\pi}-\beta \phi E_{t} \frac{u_{c}(t+1)}{u_{c}(t)}\left(\frac{\pi_{t+1}}{\pi}-1\right) \frac{\pi_{t+1}}{\pi} \frac{y_{t+1}}{y_{t}}
\end{aligned}
$$

The integrals implied by the expectations terms on the right-hand side are evaluated using numerical quadratures.

3. Check convergence of the decision rules. If $\left|f_{i}^{b}-f_{i-1}^{b}\right|$ or $\left|f_{i}^{w}-f_{i-1}^{w}\right|$ or $\left|f_{i}^{\pi}-f_{i-1}^{\pi}\right|$ is above the desired tolerance (set to $1 e-5$ ), go back to step 2 ; otherwise, $f_{i}^{b}, f_{i}^{w}$ and $f_{i}^{\pi}$ are the decision rules. 


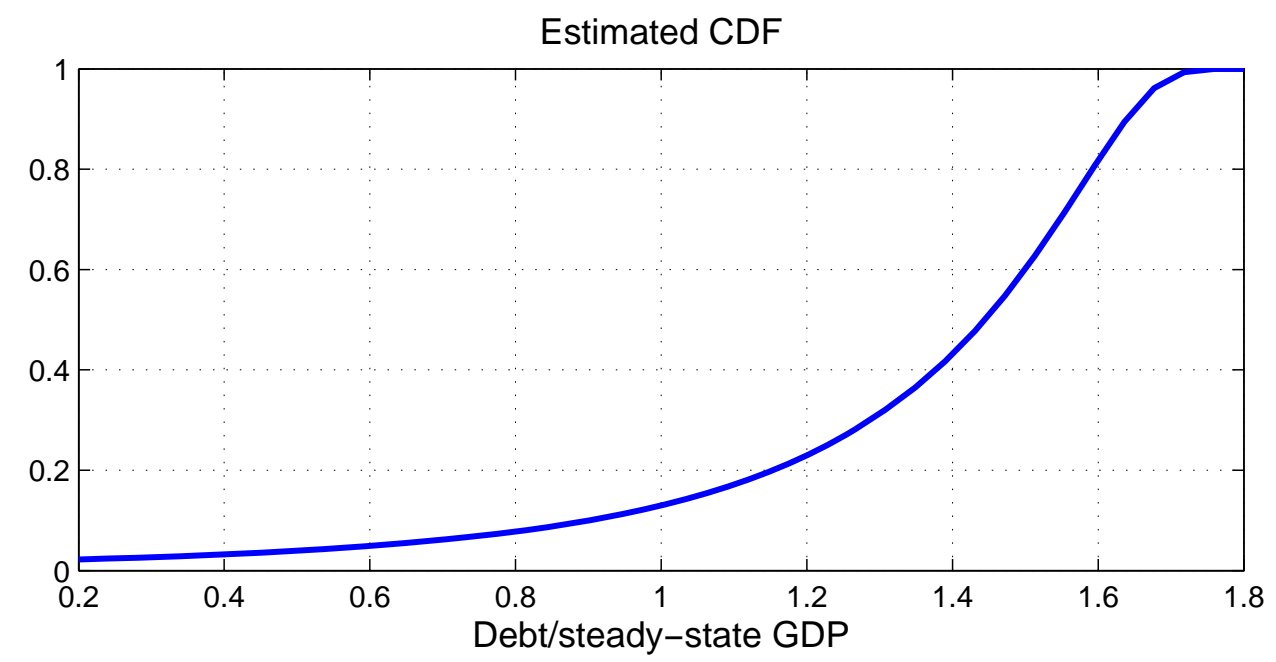

Figure 1: Cumulative Distribution of Fiscal Limit 


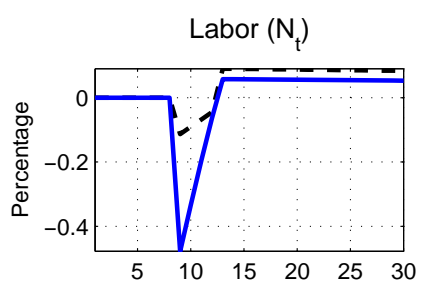

Consumption $\left(c_{t}\right)$

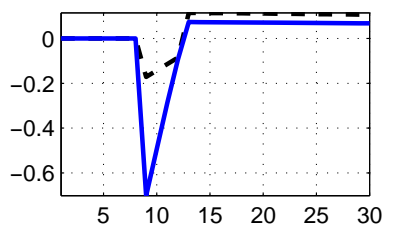

FC probability

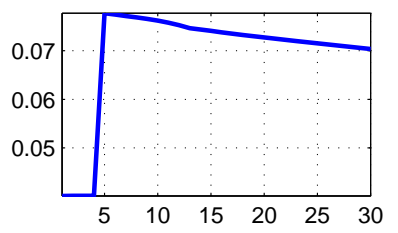

Tax rate $\left(\tau_{t}\right)$

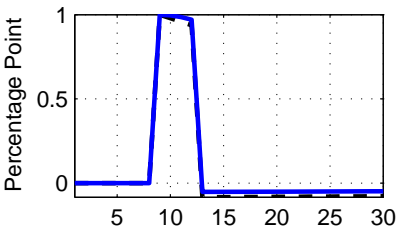

Ex-post real interest rate $\left(r_{t}\right)$

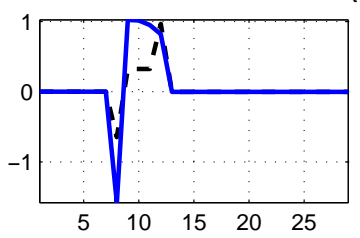

Inflation $\left(\pi_{t}\right)$

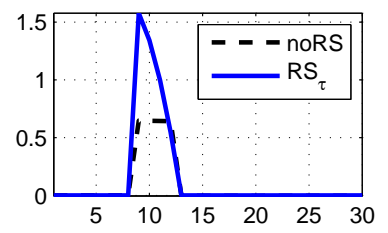

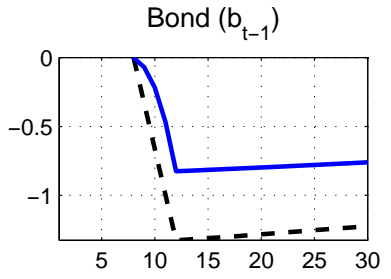

wage $\left(w_{t}\right)$

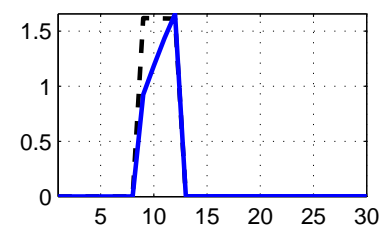

Expected Inflation

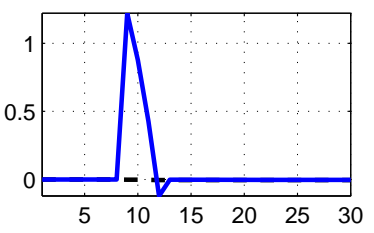

Figure 2: Impulse Response: no-RS vs. $r s^{\tau}$ model (initial probability of consolidation $=0.08$ )
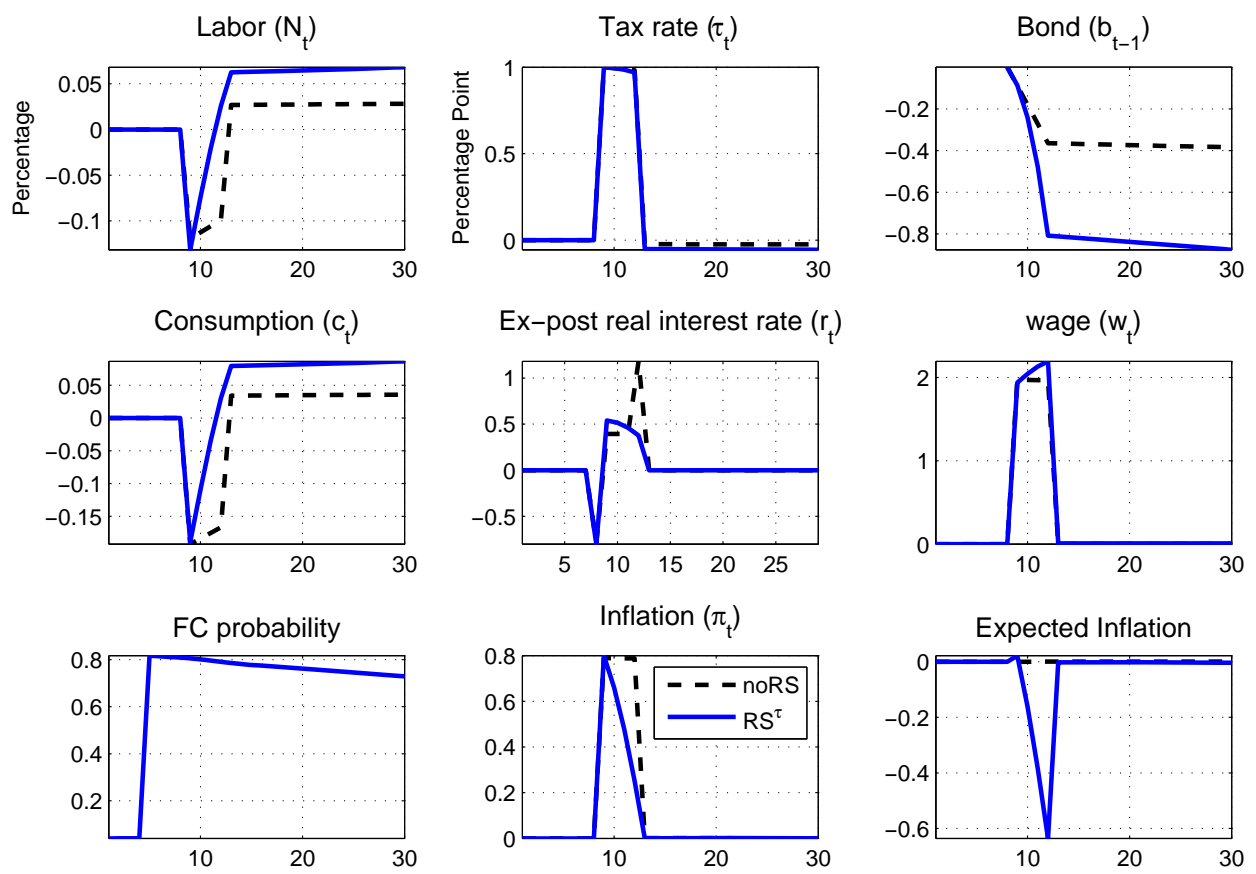

Figure 3: Impulse Response: no-RS vs. $r s^{\tau}$ model (initial probability of consolidation $=0.82$ ) 

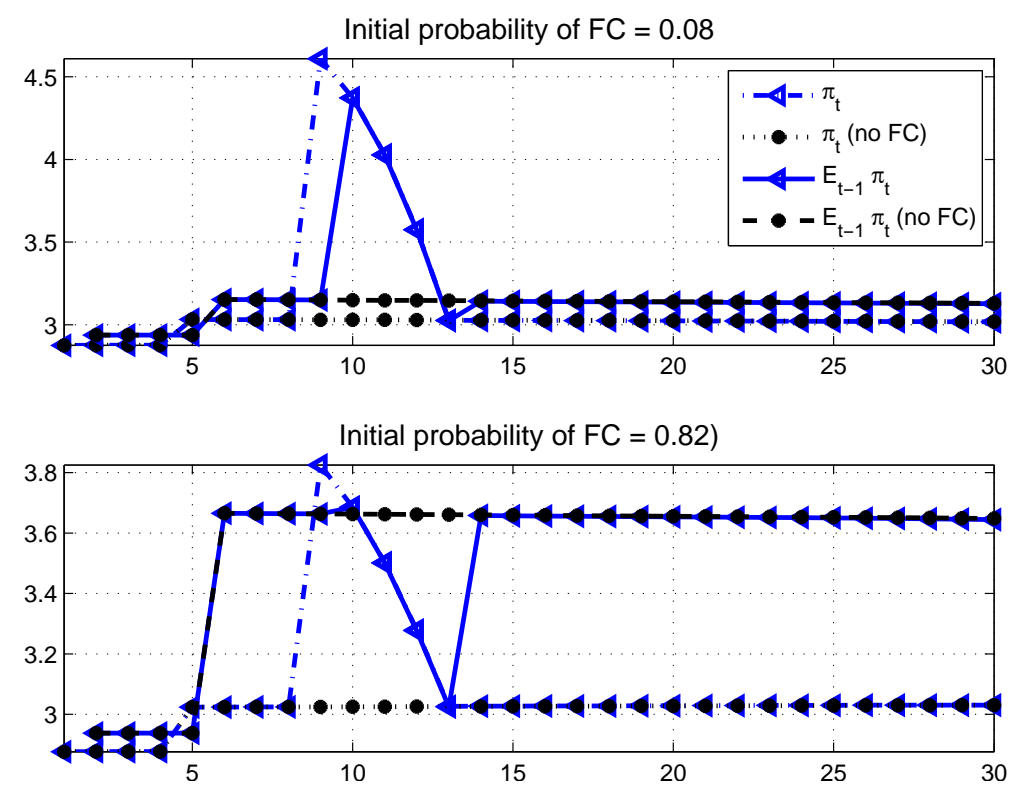

Figure 4: Inflation dynamics in the $r s^{\tau}$ model
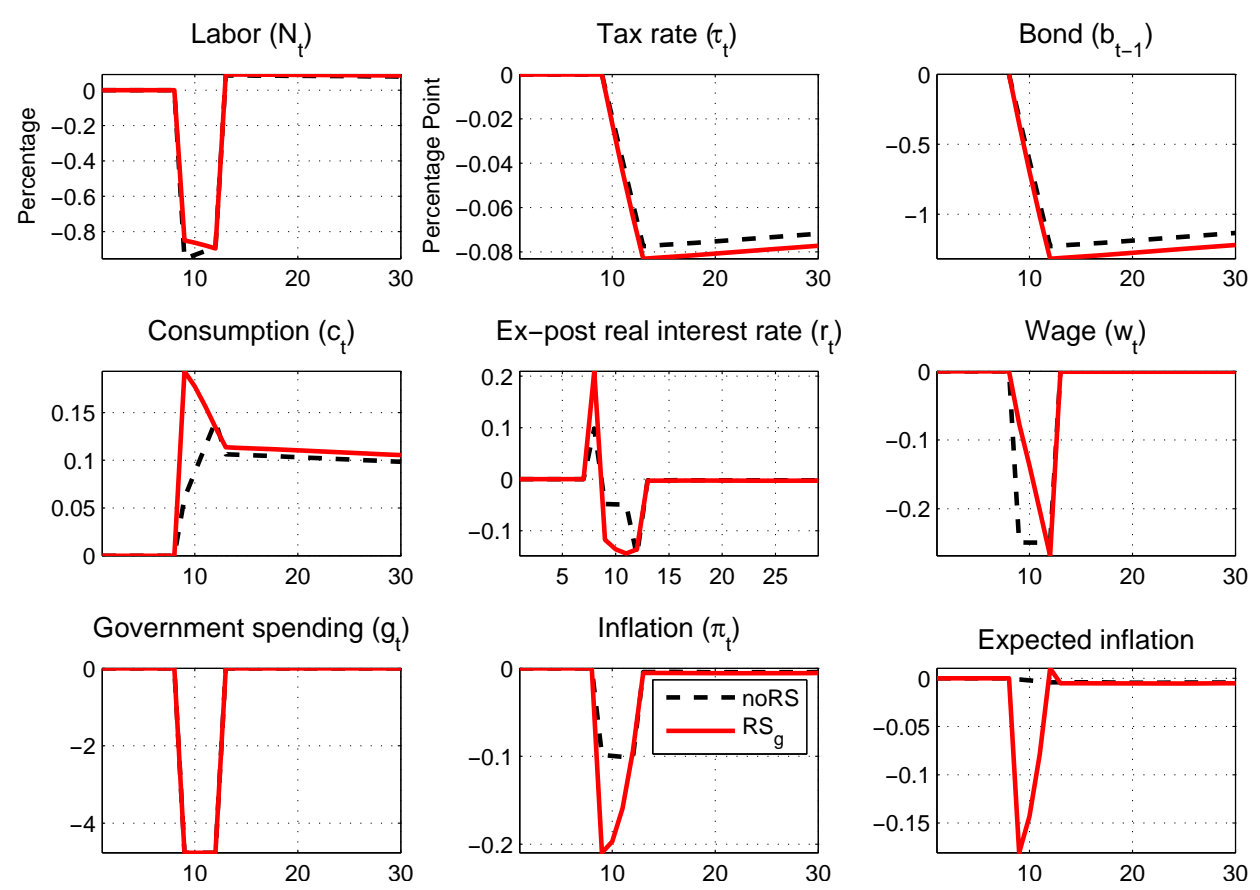

Figure 5: Impulse Response: no-RS vs. $r s^{g}$ model (initial probability of consolidation $=0.08$ ) 

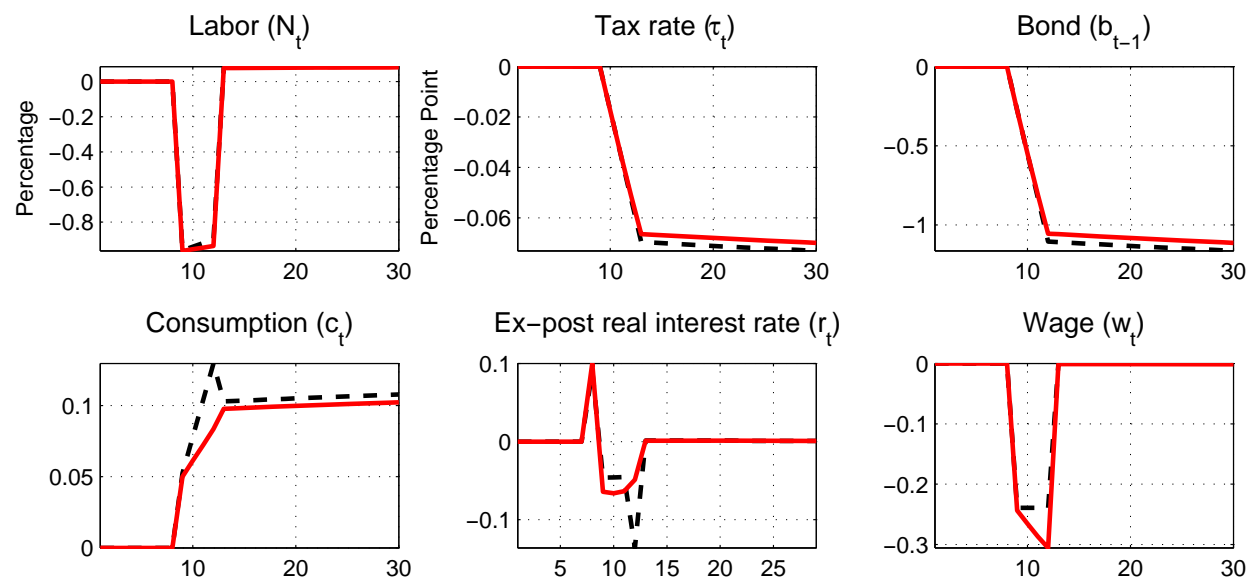

Government spending $\left(g_{t}\right)$
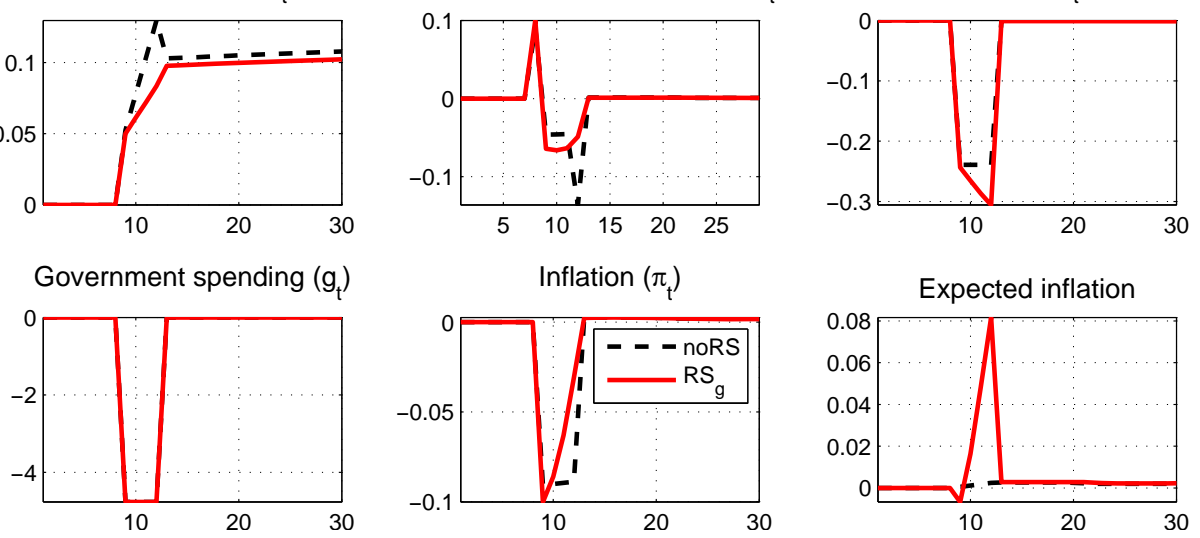

Figure 6: Impulse Response: no-RS vs. $r s^{g}$ model (initial probability of consolidation $=0.82$ )
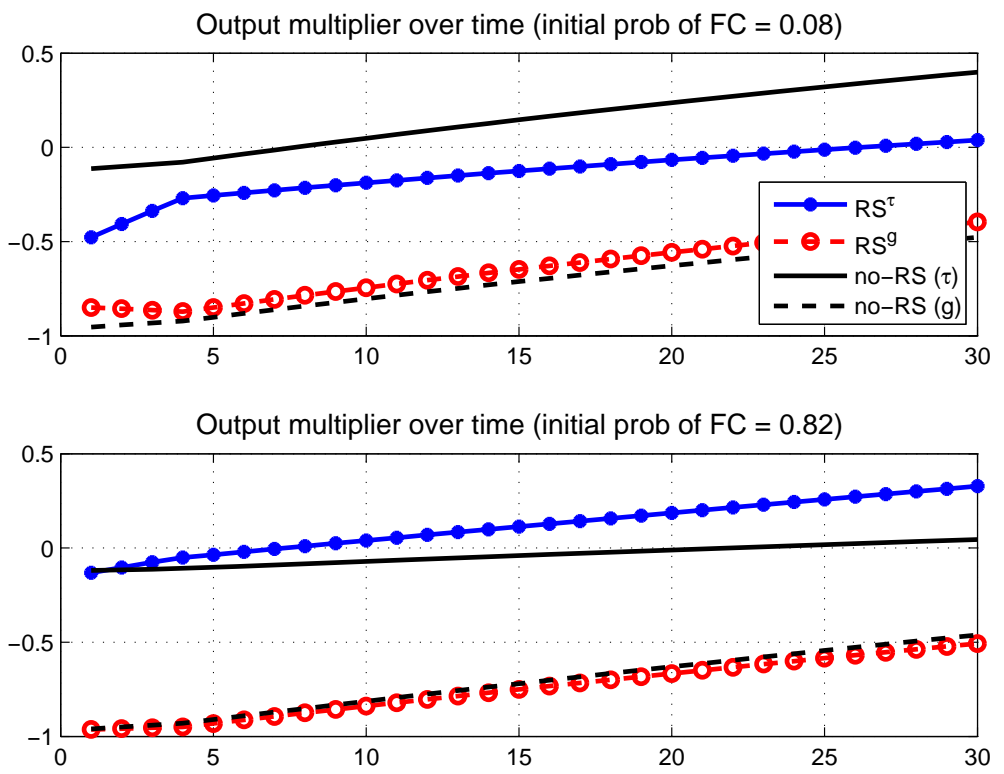

Figure 7: Output Multiplier: no-RS vs. $r s^{\tau}$ vs. $r s^{g}$ model 


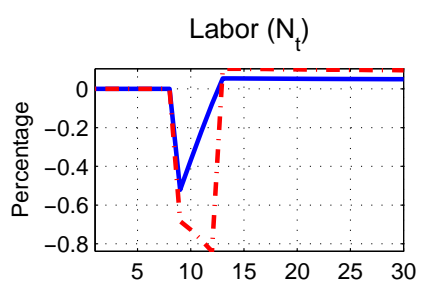

Consumption $\left(c_{t}\right)$

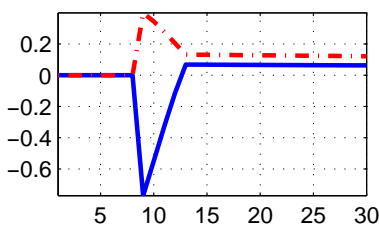

Government spending $\left(g_{t}\right)$

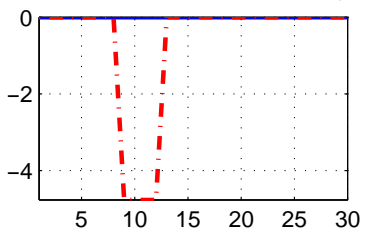

Tax rate $\left(\tau_{t}\right)$

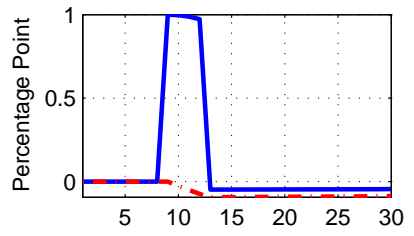

Ex-post real interest rate $\left(r_{t}\right)$

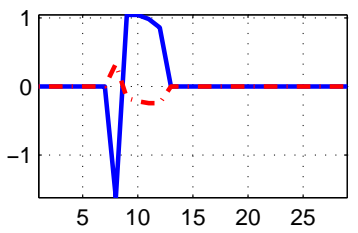

Inflation $\left(\pi_{t}\right)$

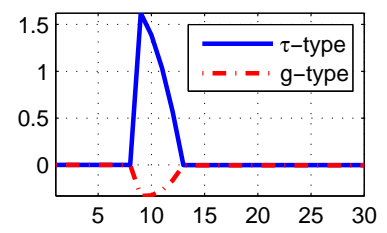

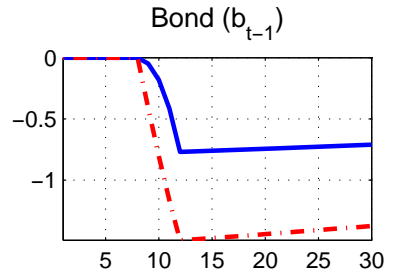

Wage $\left(w_{t}\right)$

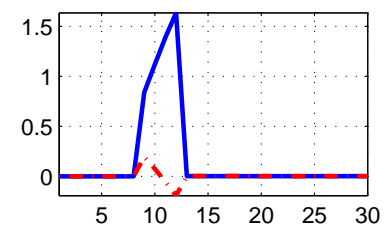

Expected Inflation

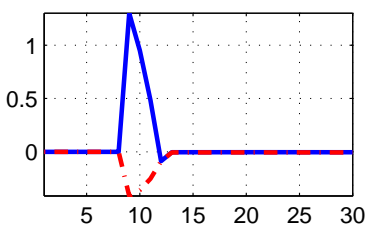

Figure 8: Impulse Response: RS model (initial probability of consolidation $=0.08$ )
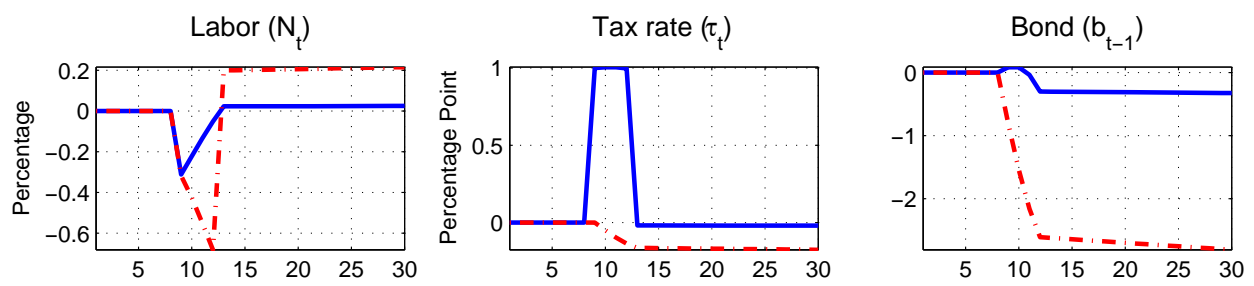

Consumption $\left(c_{t}\right)$
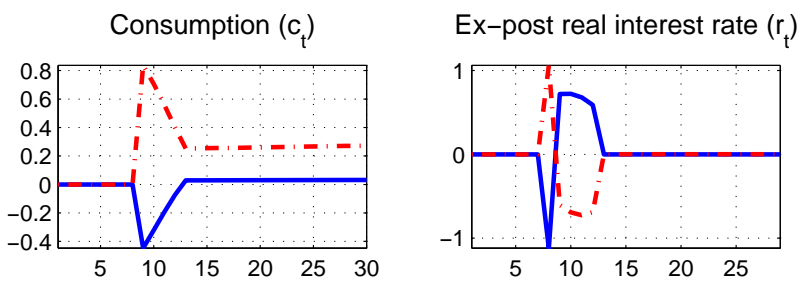

Wage $\left(w_{t}\right)$
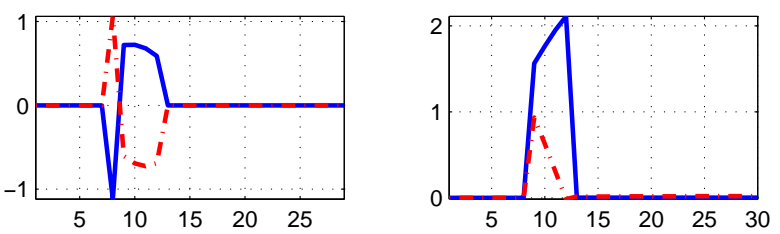

Government spending $\left(g_{t}\right)$
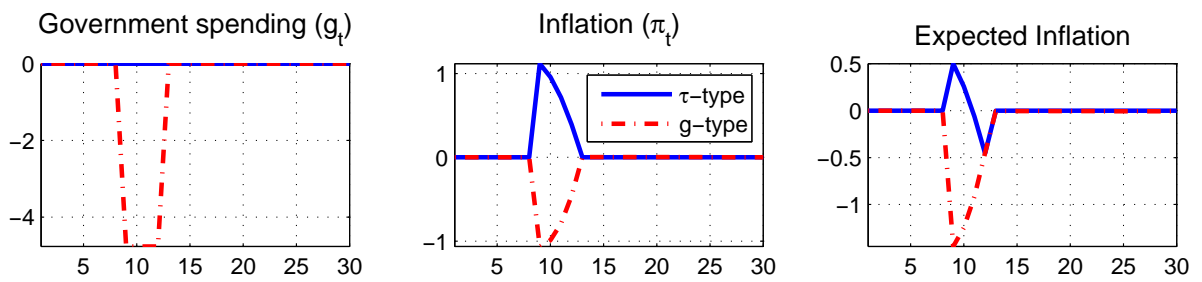

Figure 9: Impulse Response: RS model (initial probability of consolidation $=0.82$ ) 


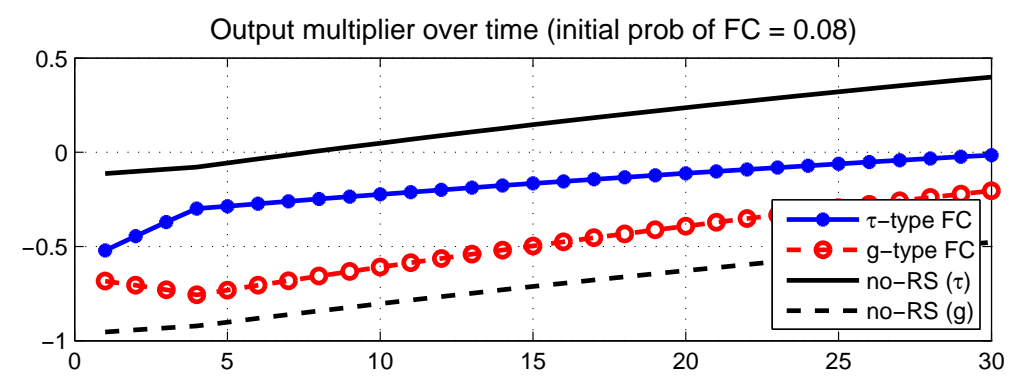

Output multiplier over time (initial prob of $F C=0.82$ )

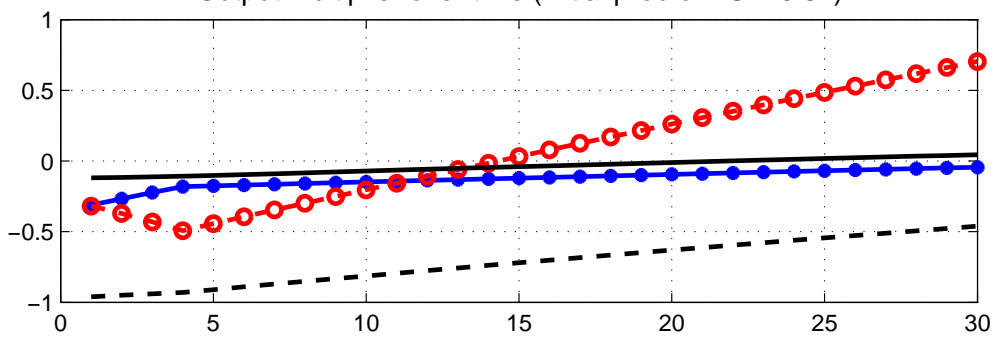

Figure 10: Output Multiplier: no-RS vs. $R S$ model
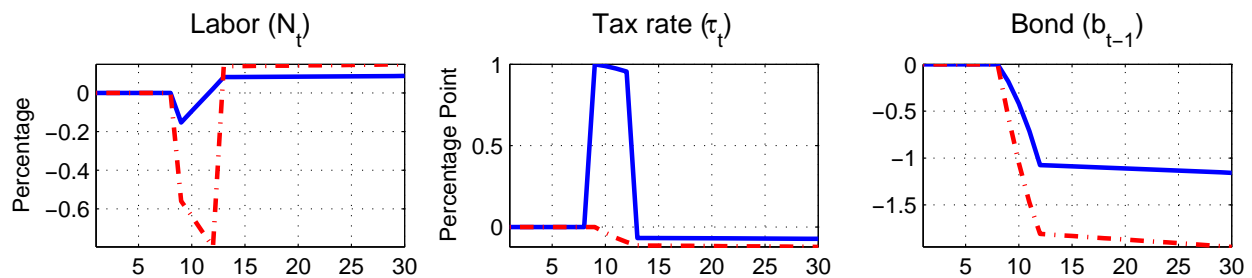

Consumption $\left(c_{t}\right)$
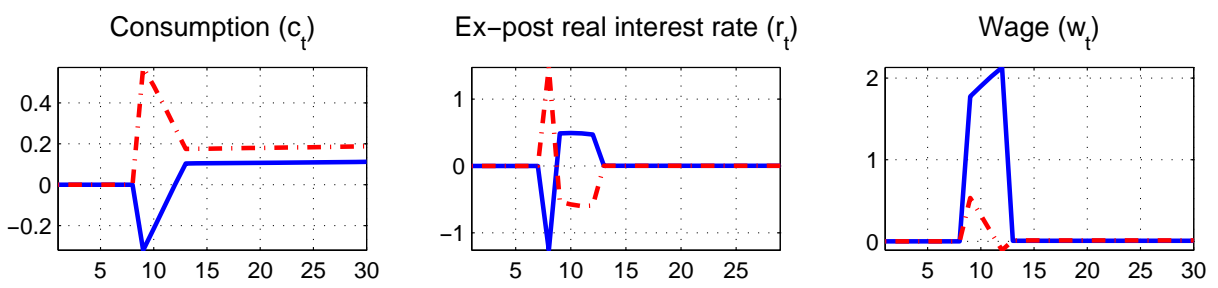

Government spending $\left(g_{t}\right)$
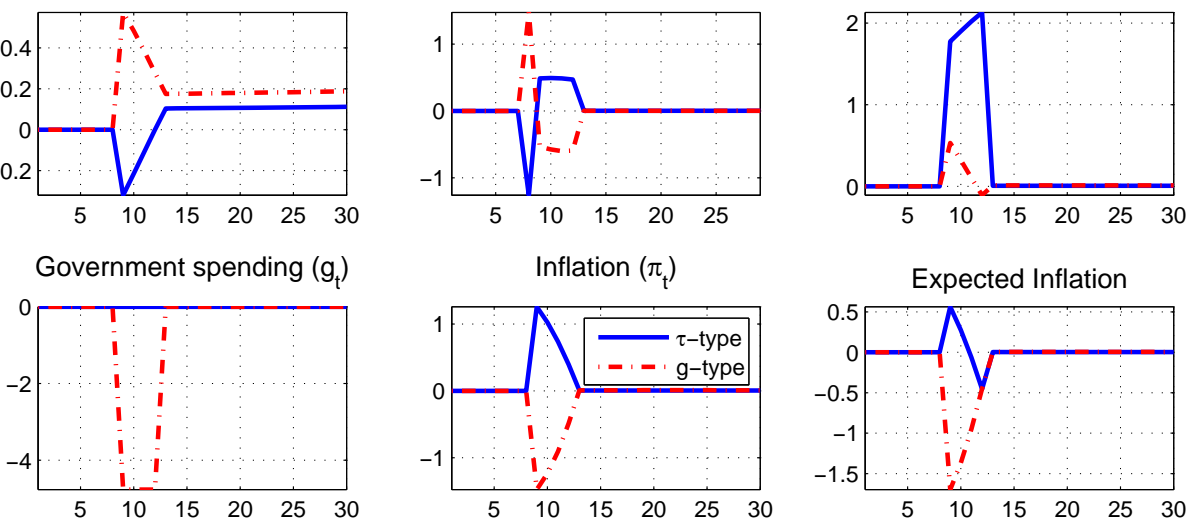

Figure 11: Impulse Response under less active monetary policy: RS model (initial probability of consolidation $=0.82$ ) with $\alpha=1.2$ 

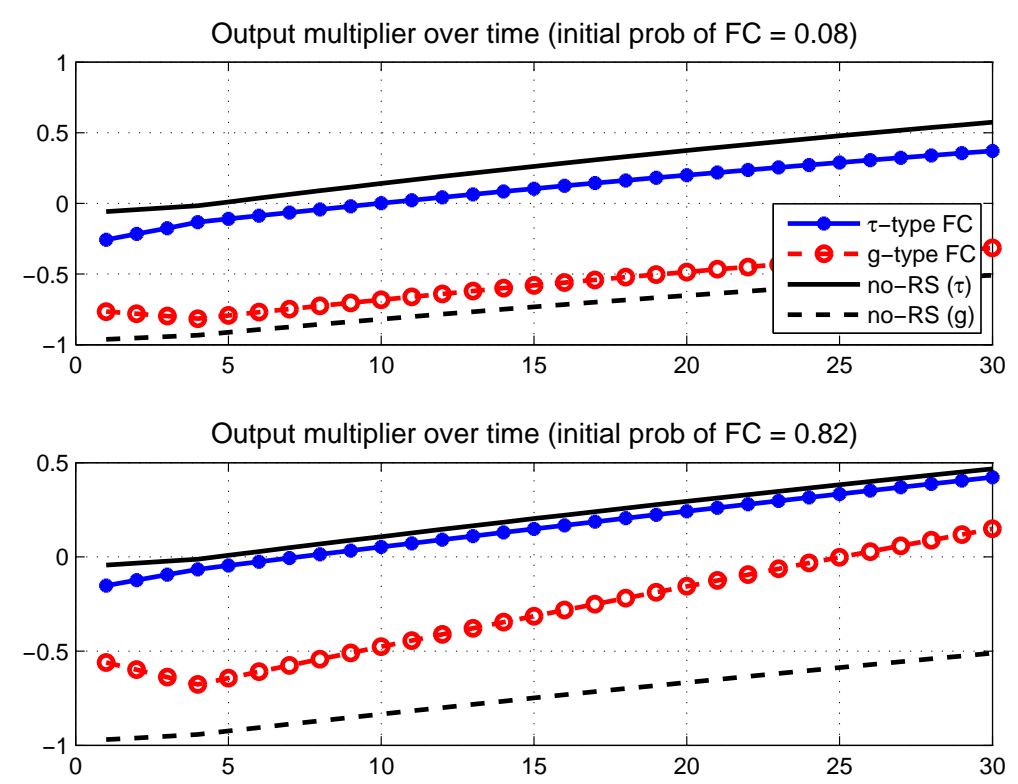

Figure 12: Output Multiplier: no-RS vs. $R S$ model with less active monetary policy
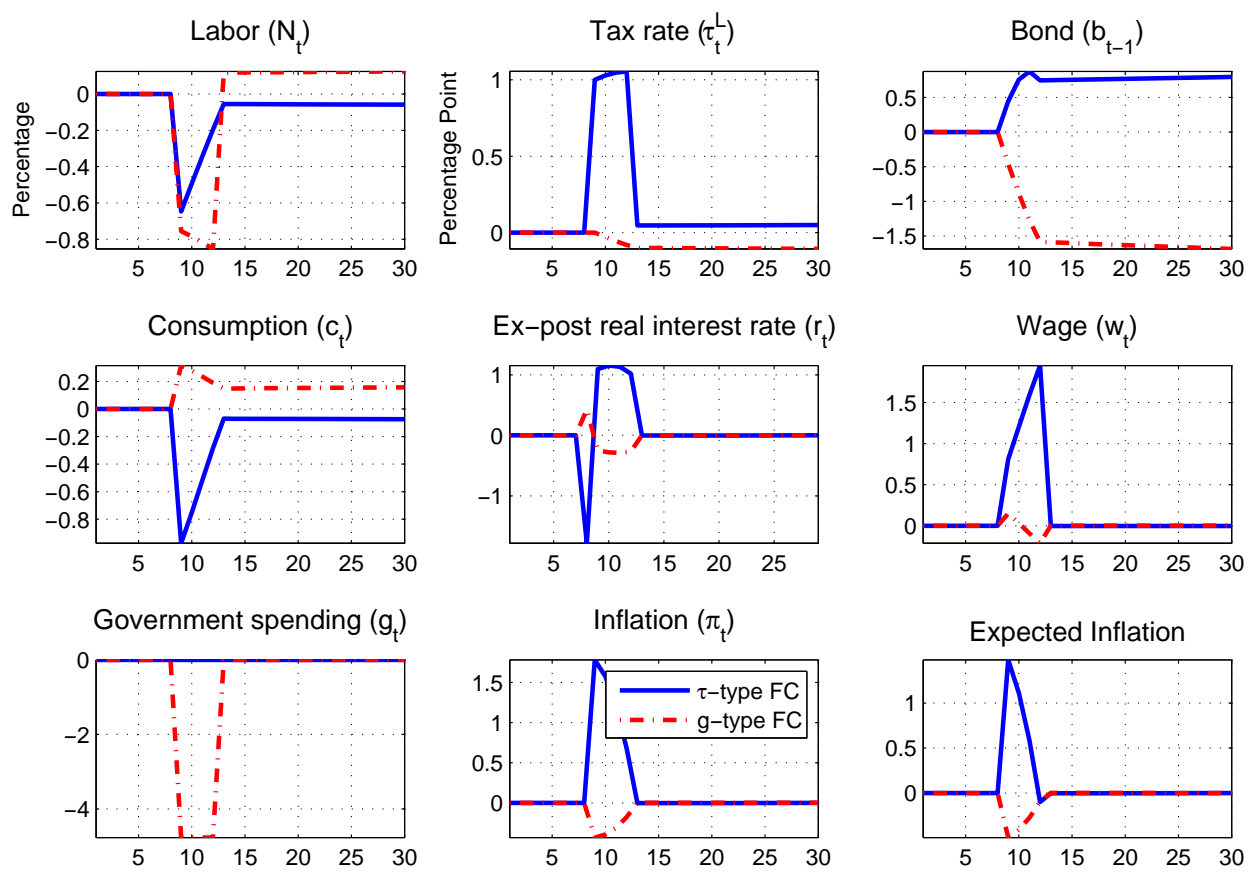

Figure 13: Impulse Response under $\omega=0.25$ : RS model (initial probability of consolidation $=0.82$ ) 


\begin{tabular}{|c|c|c|}
\hline Debt & $\begin{array}{c}\text { Expansionary } \\
-4.93^{*} \\
(1.69)\end{array}$ & $\begin{array}{c}\text { Contractionary } \\
5.42^{*} \\
(1.41)\end{array}$ \\
\hline Change in Debt & $\begin{array}{l}-0.54 \\
(1.21)\end{array}$ & $\begin{array}{c}-2.22^{*} \\
(0.53)\end{array}$ \\
\hline Total Deficit & $\begin{array}{c}-3.05^{*} \\
(0.52)\end{array}$ & $\begin{array}{c}-1.56^{*} \\
(0.33)\end{array}$ \\
\hline Primary Deficit & $\begin{array}{c}-2.54^{*} \\
(0.58)\end{array}$ & $\begin{array}{c}-1.91^{*} \\
(0.31)\end{array}$ \\
\hline Primary Expenditures & $\begin{array}{c}-2.19^{*} \\
(0.65)\end{array}$ & $\begin{array}{c}-0.80^{*} \\
(0.34)\end{array}$ \\
\hline Transfers & $\begin{array}{l}-0.58 \\
(0.41) \\
\end{array}$ & $\begin{array}{c}0.47^{*} \\
(0.17) \\
\end{array}$ \\
\hline Govt Wage Exp. & $\begin{array}{c}-0.40^{*} \\
(0.17)\end{array}$ & $\begin{array}{c}-0.40^{*} \\
(0.13)\end{array}$ \\
\hline Govt non-Wage Exp. & $\begin{array}{l}-0.13 \\
(0.12)\end{array}$ & $\begin{array}{c}0.14 \\
(0.08)\end{array}$ \\
\hline Subsidies & $\begin{array}{c}-0.32^{*} \\
(0.11)\end{array}$ & $\begin{array}{c}-0.16^{*} \\
(0.05)\end{array}$ \\
\hline Govt Investment & $\begin{array}{c}-0.76^{*} \\
(0.25)\end{array}$ & $\begin{array}{c}-0.83^{*} \\
(0.15)\end{array}$ \\
\hline Total Rev & $\begin{array}{c}0.35 \\
(0.42)\end{array}$ & $\begin{array}{l}1.11^{*} \\
(0.24)\end{array}$ \\
\hline Income Tax & $\begin{array}{c}0.16 \\
(0.33)\end{array}$ & $\begin{array}{c}0.27 \\
(0.17)\end{array}$ \\
\hline Business Tax & $\begin{array}{l}0.81 * \\
(0.36)\end{array}$ & $\begin{array}{l}0.39^{*} \\
(0.14)\end{array}$ \\
\hline Indirect Tax & $\begin{array}{c}0.01 \\
(0.15)\end{array}$ & $\begin{array}{c}0.27^{*} \\
(0.12)\end{array}$ \\
\hline Soc. Sec, Contributions & $\begin{array}{l}-0.06 \\
(0.22)\end{array}$ & $\begin{array}{c}0.14 \\
(0.13)\end{array}$ \\
\hline
\end{tabular}

Table 1: Expansionary and contractionary fiscal consolidations in AA data (size and composition): * denotes statistical significance at the 5 percent level, all variables are the average changes in the variable relative to GDP in the two years preceeding and following a fiscal consolidation. The standard errors are in brackets. 


\begin{tabular}{l|l|c}
\hline \hline & Parameter & Calibration \\
\hline Discount factor & $\beta$ & 0.99 \\
Elasticity of substitution & $\theta$ & 11 \\
Rotemberg adjustment parameter & $\phi$ & 100 \\
Inflation rate & $\pi$ & 1.03 (annual) \\
Technology & $A$ & 1 \\
Labor supply & $n$ & 0.25 \\
Government spending-GDP & $g / y$ & 0.21 \\
Government transfer-GDP & $z / y$ & 0.18 \\
Government debt-GDP & $b / y$ & $0.50($ annual) \\
Tax rate & $\tau$ & 0.41 \\
Fiscal rule parameter & $\gamma_{\tau}$ & $0.5 / 4$ \\
Taylor rule parameter & $\alpha$ & 1.5 \\
Political factor & $\beta^{p}$ & 0.85 \\
Spending shock persistence & $\rho_{g}$ & 0.9 \\
Spending shock variance & $\sigma_{g}^{2}$ & $(0.005 g)^{2}$ \\
Transfer persistence & $\rho_{z}$ & 0.9 \\
& $\zeta^{z}$ & 1.003 \\
Transfer regime parameter & $p^{z}$ & 0.975 \\
Transfer shock variance & $\sigma_{z}^{2}$ & $(0.005 z)^{2}$ \\
Length of consolidations & $h$ & 4 \\
Tax-type consolidation & $m^{\tau}$ & 0.01 \\
Spending-type consolidation & $m^{g}$ & $0.01 \mathrm{y}$ \\
Probability of tax-type FC & $\omega$ & 0.75 \\
\hline \hline
\end{tabular}

Table 2: Model Calibration 